Review

\title{
Lithium Metal Anode for High-Power and High-Capacity Rechargeable Batteries
}

Nobuyuki Imanishi ${ }^{1}$, Tao Zhang ${ }^{2}$, Daisuke Mori ${ }^{1}$, Sou Taminato ${ }^{1}$, Yasuo Takeda ${ }^{1}$, Osamu Yamamoto $1, *$

1. Graduate School of Engineering, Mie University, Tsu, Mie, 514-8507, Japan; E-Mails: imanishi@chem.mie-u.ac.jp; daisuke.mori@chem.mie-u.ac.jp; taminato@chem.mie-u.ac.jp; takeda@chem.mie-u.ac.jp; yamamoto@chem.mie-u.ac.jp

2. The State Key Laboratory of High Performance Ceramics and Superfine Microstructure, Shanghai Institute of Ceramics, CAS, Shanghai, 200050, People's Republic China; E-Mail: taozhang@mail.sic.ac.cn

* Correspondence: Osamu Yamamoto; E-Mail: yamamoto@chem.mie-u.ac.jp

Academic Editor: Ahamed Irshad

Special Issue: Batteries: Past, Present and Future

Journal of Energy and Power Technology

2021, volume 3, issue 2

doi:10.21926/jept.2102019
Received: February 21,2021

Accepted: April 21,2021

Published: May 08,2021

\begin{abstract}
Because lithium metal exhibits high specific capacity and low potential, it is the best candidate for fabricating anodes for batteries. Rechargeable batteries fabricated using lithium anode exhibit high capacity and high potential cathode; these can be potentially used to fabricate high energy density batteries ( $>500 \mathrm{Wh} \mathrm{kg}^{-1}$ ) that can be used for the development of nextgeneration electric vehicles. However, the formation and growth of lithium dendrites and the low coulombic efficiency recorded during lithium plating and stripping under conditions of high current density hinder the use of lithium metal as the anodic material for the development of practical rechargeable batteries. In this short review, we outline the current status and prospects of lithium anodes for fabricating batteries in the presence of nonaqueous liquid, polymer, and solid electrolytes operated under conditions of high current density.
\end{abstract}

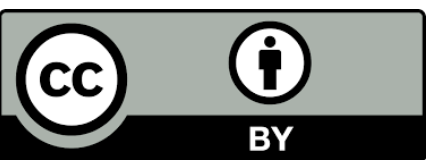




\section{Keywords}

Rechargeable battery; lithium anode; high power density; long cycle life; high coulombic efficiency; lithium dendrite

\section{Introduction}

The demand for electric vehicles (EVs) has recently increased because of their ability to reduce the emission of carbon dioxide. The low carbon dioxide emission is attributed to the significantly higher total energy conversion efficiency exhibited by EVs as compared to that exhibited by conventional internal combustion engines. If the sources of electricity are restricted to hydro, solar, wind, and nuclear power, the total carbon dioxide emissions from power generation and EVs would be almost zero. It is important to develop cost-efficient rechargeable batteries exhibiting high energy and power density to increase the global demand for EVs [1, 2]. Lithium-ion batteries are presently the primary advanced batteries used in EVs. These consist of a carbon anode, a nonaqueous electrolyte, and a lithium oxide intercalation compound. However, the specific energy density of the lithium-ion batteries is less than $250 \mathrm{Wh} \mathrm{kg}^{-1}$ (and $680 \mathrm{Wh} \mathrm{L}^{-1}$ ), whereas the specific energy density target at the cell level is $500 \mathrm{Wh} \mathrm{kg}^{-1}$ (or higher) [3]. Therefore, various types of batteries beyond conventional lithium-ion batteries have been developed and studied. Table 1 lists the high energy density rechargeable batteries that are presently under development.

Table 1 High energy density rechargeable batteries

\begin{tabular}{|c|c|c|c|c|c|}
\hline System & Anode & Cathode & Cell voltage(V) & $\begin{array}{l}\text { Theoretical energy } \\
\text { Density }\left(\mathrm{Wh} \mathrm{kg}^{-1}\right)\end{array}$ & Ref. \\
\hline Non-aqueous & $\mathrm{Li}$ & Oxygen & 3.0 & 3505 & {$[4]$} \\
\hline \multicolumn{6}{|l|}{ Li-oxygen } \\
\hline Li-sulfur & $\mathrm{Li}$ & Sulfur & 2.2 & 2567 & {$[4]$} \\
\hline Aqueous & $\mathrm{Li}$ & Air & 3.2 & 1910 & {$[5]$} \\
\hline \multicolumn{6}{|l|}{ Li-air } \\
\hline Zn-air & $\mathrm{Zn}$ & Air & 1.65 & 1086 & [4] \\
\hline Li-metal & $\mathrm{Li}$ & $\mathrm{LiNi}_{0.6} \mathrm{Mn}_{0.2} \mathrm{Co}_{0.2} \mathrm{O}_{2}$ & 3.8 & 988 & {$[6]$} \\
\hline Li-ion & Carbon & $\mathrm{LiCoO}_{2}$ & 3.8 & 387 & {$[4]$} \\
\hline
\end{tabular}

Non-aqueous lithium-oxygen batteries have the potential to generate the maximum specific energy density. These have been extensively studied in the past two decades [4, 7-9], with the first study on lithium-oxygen batteries reported by Abraham and Jiang in 1996 [10]. However, there is no technological basis that validates the claims that non-aqueous lithium-air batteries with the high power density and high specific area capacity can generate the predicted high energy densities. The second highest energy density battery system is the lithium-sulfur system, which is yet to be commercialized because of certain disadvantages such as the formation of lithium dendrite at the anode and poor cycling performance exhibited by the sulfur cathode, attributable to the polysulfide shuttle. Some of the major issues with non-aqueous lithium-air batteries include contamination by 
atmospheric moisture and decomposition of the catholyte in the presence of the reaction product. However, these factors do not limit the applications of aqueous lithium-air batteries. The configuration of the aqueous lithium-air battery is complex: a water-stable lithium-ion conducting solid electrolyte and a lithium-stable lithium-ion conducting electrolyte are used at the cathodic and anodic sides, respectively [7]. Lithium-metal anode batteries with a high capacity intercalation cathode exhibit a theoretical specific energy density that is more than twice the specific energy density exhibited by the conventional lithium-ion batteries. The specific energy density of the system at the cell level was estimated to be approximately $500 \mathrm{Wh} \mathrm{kg}^{-1}$ [6]. $\mathrm{Zn}$-air batteries, which consist of a $\mathrm{Zn}$ anode, an alkaline electrolyte, and a carbon air cathode, exhibit a high theoretical energy density of $1086 \mathrm{Wh} \mathrm{kg}^{-1}$. Primary $\mathrm{Zn}$-air batteries are widely used, although rechargeable $\mathrm{Zn}$-air batteries have not yet been commercialized. The challenges with the $\mathrm{Zn}$-air system include contamination by carbon dioxide present in the air and the formation of zinc dendrite. Therefore, the air must thus be managed to remove carbon dioxide [11]. The most promising battery for EVs with a specific energy density higher than $500 \mathrm{Wh} \mathrm{kg}^{-1}$ is fabricated using a lithium metal anode. However, a stable lithium metal electrode should be developed with a long cycle life under conditions of a high current density $\left(>1 \mathrm{~mA} \mathrm{~cm}^{-2}\right)$ and a high specific area capacity $\left(>5 \mathrm{mAh} \mathrm{cm}{ }^{-2}\right)$. In this short review, we discuss the performance of the lithium-metal anode in conjunction with non-aqueous liquid electrolytes, polymer electrolytes, and solid electrolytes under conditions of high current density.

\section{Lithium Electrode in Non-Aqueous Solutions}

\subsection{Lithium Surface in Contact with Electrolytes}

All batteries with an expected high specific energy density of $>500 \mathrm{Wh} \mathrm{kg}^{-1}$ are fabricated using a lithium metal anode. Lithium metal is the best candidate to fabricate anodes for high energy density batteries because it exhibits a high capacity $\left(3860 \mathrm{mAh} \mathrm{g}^{-1}\right.$ ) and low electrochemical potential ( $-3.04 \mathrm{~V}$ vs. NHE). Rechargeable batteries fabricated using lithium metal anodes have been extensively studied for over 40 years. In 1978, Whittingham reported excellent cycle performance for a $\mathrm{Li} / \mathrm{TiS}_{2}$ battery operated at $10 \mathrm{~mA} \mathrm{~cm}^{-2}$, the theoretical energy density of which was $473 \mathrm{Wh}$ $\mathrm{kg}^{-1}$ [12]. Moli Energy in Canada commercialized rechargeable lithium metal chalcogenide batteries in the second half of the 1980s to power the cellar phones of Nippon Telegram and Telephone (NTT) in Japan. However, there were concerns regarding its safety as short circuits could be caused due to the growth of lithium dendrites. Lithium-ion batteries were subsequently commercialized. The system consisted of a carbon anode and not a lithium metal [13]. However, the specific capacity of the carbon anode was approximately one-tenth of that of the lithium anode. The formation of lithium dendrites is promoted by an uncontrolled deposition of lithium [14] through the solid electrolyte interphase (SEI) that forms on the lithium metal surface [15], as shown in Figure 1. The limiting current density $\left(\mathrm{J}^{*}\right)$ for the formation of lithium dendrite is given by the following equation:

$$
J^{*}=\left(2 e C_{0} D / t_{a} L\right)
$$

where $\mathrm{e}$ is the elementary charge, $\mathrm{C}_{0}$ is the initial concentration, $\mathrm{D}$ is the diffusion constant, $\mathrm{t}_{\mathrm{a}}$ is the anionic transport number, and $L$ is the interelectrode distance [14]. Lithium dendrites do not appear at a lower $\mathrm{J}$ * but at a higher J. The time $(\tau)$ to dendrite formation is given by the following equation: 


$$
t_{0}=\pi D\left(C_{0} e / 2 J t_{a}\right)^{2}
$$

where $t_{0}$ is Sand's time and $\mathrm{J}$ is the current density. Lithium dendrites did not form in the system consisting of a lithium electrode and thin SEI layer that exhibited high lithium-ion conductivity. According to Eq. (2), the onset time for dendrite formation is dependent on the diffusion constant of lithium ions in the electrolyte, which is related to the inverse of the passivation film resistance (determined from the Nernst and Einstein equation).

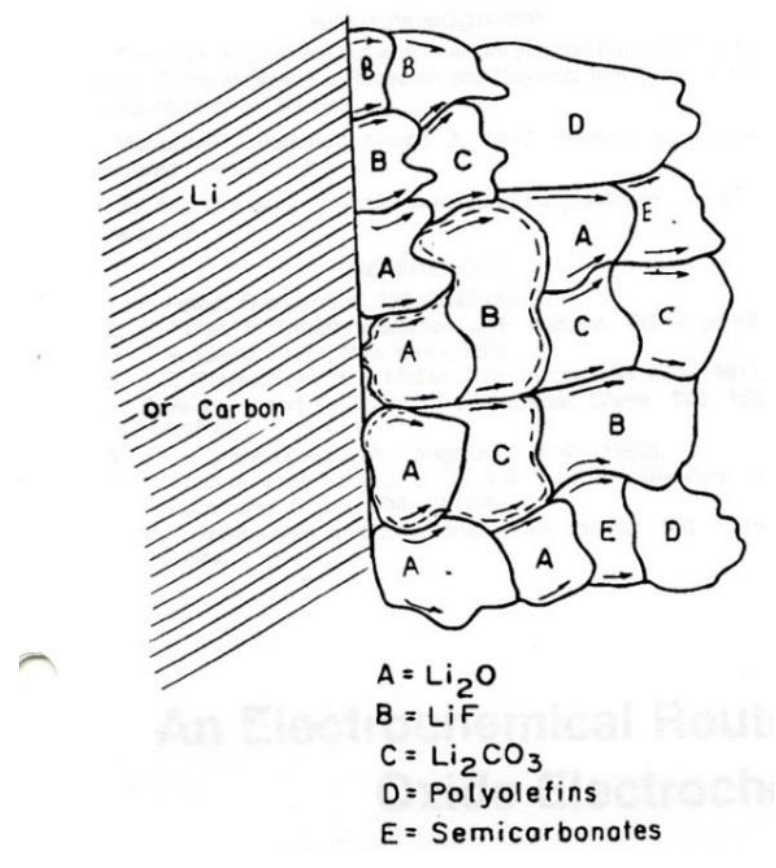

Figure 1 Schematic representation of a polyhetero microphase SEI on lithium or carbon [15].

Imanishi et al. [16] reported a linear relationship between $1 / R_{f}$ and $t_{0}$ (Figure 2 ) for a $\mathrm{Li} /$ polyethylene oxide (PEO)-based polymer electrolyte/Li cell at $60^{\circ} \mathrm{C}$ when the current density was $0.5 \mathrm{~mA} \mathrm{~cm}^{-2}$. $\mathrm{R}_{\mathrm{f}}$ denotes the specific interface resistance. PEO-lithium bis(trifluoromethanesulfonyl)imide (LiTFSI) electrolytes were examined as polymer electrolytes with different interface resistances at the lithium metal electrode in the presence and absence of $\mathrm{SiO}_{2}$ and/or N-methyl-N-propylpiperidinium bis(trifluoromethanesulfonyl)imide (PP13TFSI). The results suggested that the formation of dendrites on the lithium metal was associated with the SEI resistance. Numerous reviews on lithium anodes in rechargeable lithium batteries have been published over the years [17-21]. In this short review, we present a perspective on the lithium metal electrodes that can be potentially used to develop high power density rechargeable lithium batteries. 


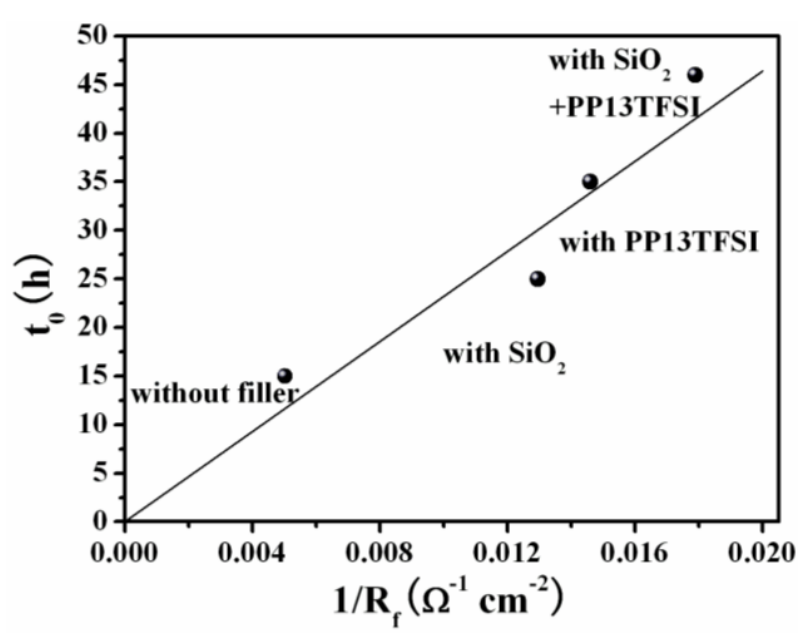

Figure 2 Relationship between the dendrite formation onset time $\left(t_{0}\right)$ and the inverse of the specific interface layer resistance between Li and a PEO-based electrolyte at $60^{\circ} \mathrm{C}$ under conditions of $0.5 \mathrm{~mA} \mathrm{~cm}^{-2}[16]$.

\subsection{Relationship between the Formation of Lithium Dendrite and the Current Density in Non- Aqueous Solutions}

The specific energy and power densities exhibited by lithium-ion battery packs that are currently used to develop modern EVs are approximately $100 \mathrm{Wh} \mathrm{kg}^{-1}$ and $1500 \mathrm{~W} \mathrm{~kg}^{-1}$, respectively. The energy and power density targets of the New Energy and Industrial Technology Development Organization (NEDO) program in Japan for the 2030s are $500 \mathrm{Wh} \mathrm{kg}^{-1}$ and $1500 \mathrm{~W} \mathrm{~kg}^{-1}$, respectively [1]. The power density has already been achieved, and we can achieve the target of $500 \mathrm{Wh} \mathrm{kg}^{-1} \mathrm{at}^{2}$ the cellular level using a lithium metal anode and a high-capacity cathode [6]. However, reports on the formation and growth of lithium dendrites have suggested that high current density and long charge/discharge cycles lead to undesirable dendrite growth [18]. Seong et al. [22] reported the effect of the amount of charge and current density on the amount of lithium dendrite formation in an electrolyte consisting of ethylene carbonate $(E C)$ and dimethyl carbonate (DMC) $(1: 1 \mathrm{v} / \mathrm{v})$ in the presence of $\mathrm{LiClO}_{4}(1 \mathrm{M})$. An empirical formula and the corresponding curves were established to indicate the relationship between the growth of lithium dendrite and the current density/amount of charge (Figure 3). The formation of lithium dendrite is dependent on the current density and the total specific capacity (the amount of deposited lithium). The maximum specific capacity of approximately $3 \mathrm{mAh} \mathrm{cm}$ is observed at around $1.0 \mathrm{~mA} \mathrm{~cm}$. Figure 4 shows the relationship between the short-circuit onset-time of a cell, consisting of Li/bis(fluorosulfonyl)imide (LiFSI) in 1,2dimethoxyethane $(\mathrm{DME}) / \mathrm{Li}$ (with a large pore size; $\sim 0.7 \mu \mathrm{m}$ ) and a Whatman glass fiber separator, as a function of the LiFSI concentration [23]. The capacities of the short-circuit for the Li/1 M LiFSI in DME/Li cell system with the glass fiber separator at $0.75,1.0$, and $2 \mathrm{~mA} \mathrm{~cm}^{-2}$ were 71, 54, and 26 $\mathrm{mAh} \mathrm{cm}^{-2}$, respectively. The capacity of the short-circuit onset-time decreased significantly when the current densities were higher than $0.75 \mathrm{~mA} \mathrm{~cm}^{-2}$. 


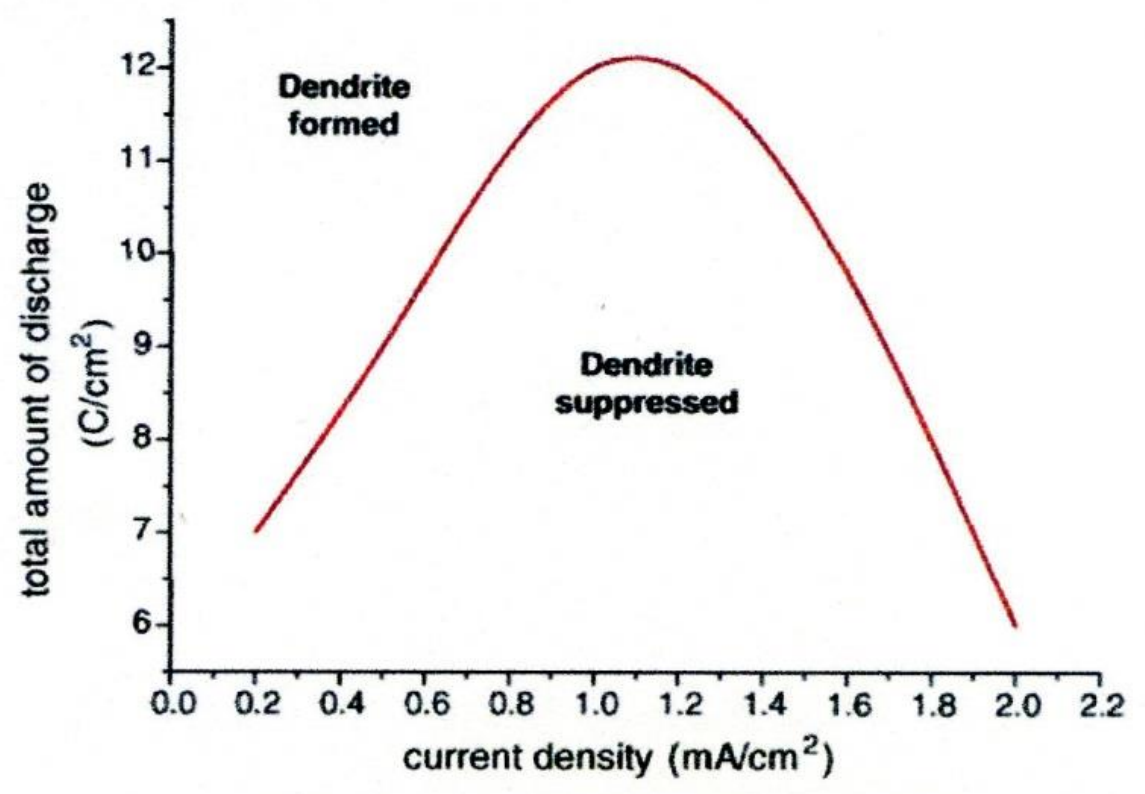

Figure 3 Relationship between the total discharge and current densities. The condition that corresponds to the area under the line represents the suppression of dendrite growth of Li deposits [22].

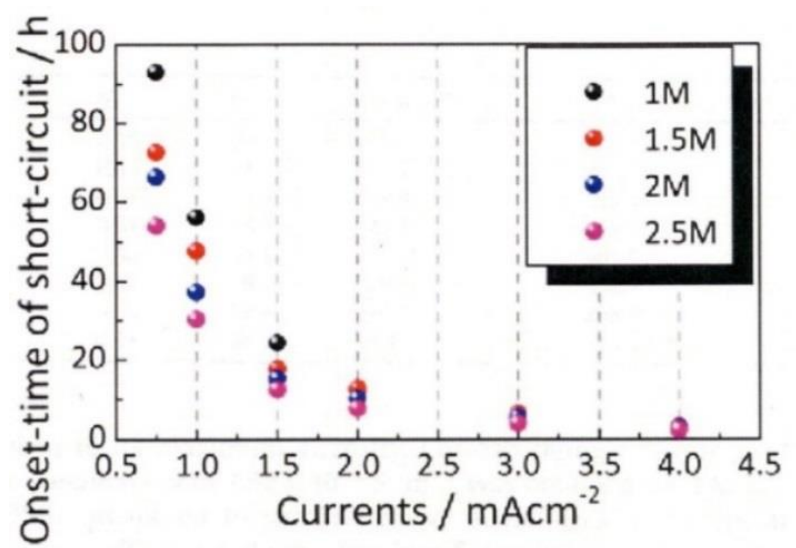

Figure 4 Short-circuit onset-time as a function of the current density for a cell consisting of Li/LiFSI in DME/Li with a Whatman glass fiber separator [23].

\subsection{Coulombic Efficiency of Lithium Deposition and Stripping in Non-Aqueous Electrolytes}

EV batteries must exhibit high coulombic efficiency (CE) under conditions of high current density and high specific energy and power densities. If $80 \%$ residual of the initial lithium is defined as the cycle life of the lithium metal anode, the lifespans of the lithium metal anodes with CEs of 99, 99.9, and $99.99 \%$ would be 22,223 , and 2231 cycles, respectively [18]. The specific energy density and CE of such batteries depend on the specific area capacity (specific capacity of the active material [mAh $\mathrm{g}^{-1}$ ] multiplied by the amount of charged active materials [ $\left.\mathrm{mg} \mathrm{cm}^{-2}\right]$ ) [24]. Figures 3 and 4 show that the rate of formation of lithium dendrite depends on the current density and the amount of charge. Table 2 shows CEs for lithium metal electrodes in typical non-aqueous electrolytes. The CEs recorded in carbonate electrolytes were higher than those recorded in ether-based electrolytes. 
The highest CE of $98.2 \%$ was reported for $\mathrm{LiPF}_{6}$ in fluoroethylene carbonate (FEC). A high CE in the presence of a non-aqueous electrolyte was recorded in the presence of high content of lithium salt and certain additives such as $\mathrm{LiNO}_{3}$. Table 3 summarizes the properties of lithium electrodes exhibiting high CEs in non-aqueous electrolytes. The LiTFSI (10 M) system in the EC-DME electrolyte showed a high CE of 99.2\%. The CE of $98.2 \%$ recorded for $1 \mathrm{M}$ of $\mathrm{LiPF}_{6}$ in FEC increased to $99.6 \%$ in the presence of LiFSI (7 M) in FEC. The recorded CE was comparable to that of the graphite electrode in an electrolyte consisting of $\mathrm{LiPF}_{6}(1.2 \mathrm{M})$ in EC-ethyl methyl carbonate (EMC) [25]. Electrolytes with a high content of LiFSI or LiTFSI are unfavorable for the development of large-capacity batteries because these are expensive, and a high content of lithium salt solutions generate high viscosity. The addition of certain salts, such as $\mathrm{LiF}$ [26], $\mathrm{LiNO}_{3}$ [27-30], and $\mathrm{Li}_{2} \mathrm{~S}_{8}$ [27] in the electrolytes resulted in improved CE. The addition of $\mathrm{LiF}, \mathrm{LiNO}_{3}$, and $\mathrm{Li}_{2} \mathrm{~S}_{8}$ in liquid electrolytes reduced the amount of lithium dendrite formation due to the generation of stable and uniform SEI layers. During the initial cycling process, the reduction products of $\mathrm{LiNO}_{3}$ and $\mathrm{Li}_{2} \mathrm{~S}_{8}$, such as $\mathrm{LiN}_{\mathrm{x}} \mathrm{O}_{y}$ and $\mathrm{Li}_{2} \mathrm{~S} / \mathrm{Li}_{2} \mathrm{~S}_{2}$, were deposited simultaneously on the lithium electrode. These reduction product layers were smooth and compact, and the formation of the potential active sites for lithium dendrite nucleates could be effectively avoided. This suppressed the formation of lithium dendrite and further reactions between lithium and electrolyte [31]. The addition of $1 \mathrm{w} / \mathrm{o}$ of $\mathrm{LiNO}_{3}$ and $0.18 \mathrm{M}$ of $\mathrm{Li}_{2} \mathrm{~S}_{8}$ in a system of LiTFSI (1 M) in 1,3 dioxolane (DOL)-DME resulted in a CE of $99.4 \%$ after 120 cycles at $2.0 \mathrm{~mA} \mathrm{~cm}^{-}$ 2 and $2.0 \mathrm{mAh} \mathrm{cm}^{-2}$. The addition of $1 \mathrm{wt} . \%$ of $\mathrm{LiNO}_{3}$ alone reduced the $\mathrm{CE}$ to $90 \%$ after just 45 cycles. A stable and uniform solid-state SEI was thus formed due to the synergistic effect of both lithium polysulfide and lithium nitride (used as additives in the ether-based electrolyte).

Table 2 CE recorded during lithium deposition and stripping in typical non-aqueous electrolytes.

\begin{tabular}{|c|c|c|c|c|c|c|}
\hline \multirow[t]{2}{*}{ Solvent } & \multirow[t]{2}{*}{ Salt } & \multirow{2}{*}{$\begin{array}{l}\text { Counter } \\
\text { electrode }\end{array}$} & \multicolumn{2}{|c|}{ Current } & \multirow[t]{2}{*}{ CE(\%) } & \multirow[t]{2}{*}{ Ref } \\
\hline & & & Density $\left(\mathrm{mA} \mathrm{cm}^{-2}\right)$ & Period (h) & & \\
\hline EC & $1 \mathrm{M} \mathrm{LiPF}_{6}$ & $\mathrm{Cu}$ & 0.1 & 15 & 94.8 & [32] \\
\hline PC & $1 \mathrm{M} \mathrm{LiPF}_{6}$ & $\mathrm{Cu}$ & 0.1 & 15 & 76.5 & [32] \\
\hline FEC & $1 \mathrm{M} \mathrm{LiPF}_{6}$ & $\mathrm{Cu}$ & 0.1 & 15 & 98.2 & [32] \\
\hline DME & 1 M LiFSI & SS & 0.25 & 2.5 & $75-80$ & [33] \\
\hline EC-THF $(1: 1 \mathrm{v} / \mathrm{v})$ & $1 \mathrm{M} \mathrm{LiPF}_{6}$ & $\mathrm{Ni}$ & 0.6 & 0.14 & $74-78$ & [34] \\
\hline EC-DME $(1: 1 \mathrm{v} / \mathrm{v})$ & $1 \mathrm{M}$ LiBETI & $\mathrm{Ni}$ & 0.6 & 0.14 & $87-88$ & [34] \\
\hline EC-DMC $(1: 1 \mathrm{v} / \mathrm{v})$ & $1 \mathrm{M} \mathrm{LiPF}_{6}$ & $\mathrm{Ni}$ & 1.0 & 4.0 & $80-85$ & [35] \\
\hline
\end{tabular}

THF: tetrahydrofuran; LiBETI: lithium bis(perfluoroethylsulfonylimide).

Table 3 CE recorded during lithium deposition and stripping in non-aqueous electrolytes with high CE.

\begin{tabular}{llllllll}
\hline Solvent & Salt & $\begin{array}{l}\text { Counter } \\
\text { electrode }\end{array}$ & $\begin{array}{c}\text { Current } \\
\text { Density }\left(\mathrm{mA} \mathrm{cm}^{-2}\right)\end{array}$ & $\begin{array}{l}\text { Cycle } \\
\text { Period } \\
(\mathrm{h})\end{array}$ & CE(\%) & Ref. \\
\hline PEC & $7 \mathrm{M} \mathrm{LiFSI}$ & $\mathrm{Cu}$ & 0.25 & 2 & 400 & 99.6 & {$[36]$} \\
DMC-BTFE & $2.5 \mathrm{M} \mathrm{LiFSI}$ & $\mathrm{Cu}$ & 0.5 & 10 & 10 & 99.5 & {$[37]$} \\
DOL-DME & $1 \mathrm{M} \mathrm{LiTFSI}$ & $\mathrm{Cu}$ & 2.0 & 1 & 60 & 99.4 & {$[27]$}
\end{tabular}




\begin{tabular}{llllllll} 
& $1 \mathrm{~W} / \mathrm{OLiNO}_{3}$ & & & & & & \\
& $0.18 \mathrm{M} \mathrm{Li}_{2} \mathrm{~S}_{8}$ & & & & & & \\
EC-DME & $10 \mathrm{M} \mathrm{LiTFSI}$ & $\mathrm{Cu}$ & 0.2 & 5 & 20 & 99.2 & [38] \\
EC-EMC & $1.2 \mathrm{M} \mathrm{LiPF}_{6}$ & Graphite & 0.23 & 5 & 20 & 99.6 & {$[25]$} \\
\hline
\end{tabular}

BTFE: bis(2, 2, 2-trifluoroethyl) ether.

\subsection{Formation of Lithium Dendrites in Non-Aqueous Electrolytes}

Analysis of Figures 3 and 4 reveals that the onset-time of lithium dendrite formation in a nonaqueous electrolyte is dependent on the current density. Lithium-ion batteries fabricated with a carbon anode are generally operated under conditions of several $\mathrm{mA} \mathrm{cm}{ }^{-2}$ and $\mathrm{mAh} \mathrm{cm} \mathrm{cm}^{-2}$. According to the report by Seong et al. [22], lithium dendrites were observed after $9.7 \mathrm{~h}$ of polarization at 0.2 $\mathrm{mA} \mathrm{cm}{ }^{-2}\left(1.94 \mathrm{mAh} \mathrm{cm} \mathrm{cm}^{-2}\right), 3.3 \mathrm{~h}$ of polarization at $1.0 \mathrm{~mA} \mathrm{~cm}{ }^{-2}\left(3.3 \mathrm{mAh} \mathrm{cm} \mathrm{cm}^{-2}\right)$, and $0.83 \mathrm{~h}$ of polarization at $2.0 \mathrm{~mA} \mathrm{~cm} \mathrm{~cm}^{-2}\left(1.66 \mathrm{mAh} \mathrm{cm}^{-2}\right)$. The lithium anode performance should be discussed under conditions of high current densities $\left(>1 \mathrm{~mA} \mathrm{~cm}^{-2}\right.$ ) and high specific area capacities (of more than several $\mathrm{mAh} \mathrm{cm}^{-2}$ ). The lithium dendrites formed on a lithium electrode grow through the electrolyte with a separator to the counter electrode. This results in internal short-circuiting that poses a serious safety hazard. Figure 5 shows the polarization curves measured for the symmetrical $\mathrm{Li} / 4 \mathrm{M} \mathrm{LiFSI}$ system in DME/Li cells in the presence of various separators when the current density was $1.0 \mathrm{~mA} \mathrm{~cm}^{-2}$ at $25^{\circ} \mathrm{C}$. The cell without a separator became short-circuited within a polarization time of $1 \mathrm{~h}$. In contrast, the cell with a $20 \mu \mathrm{m}$-thick microporous polyethylene (Toray, 0.02-0.10 $\mu \mathrm{m}$ pore size) separator showed no short-circuit after approximately $40 \mathrm{~h}$ of polarization. The abrupt cell voltage drop could be attributed to the loss of the lithium anode. The $170 \mu \mathrm{m}$-thick Whatman glass separator with particle retention of $11 \mu \mathrm{m}$ and a $160 \mu \mathrm{m}$-thick non-woven separator (pore size: $0.18 \mu \mathrm{m}$ ) resulted in quick short-circuits within several hours of polarization. Figure 6 shows the cycle performance for a cell consisting of Li/4 M LiFSI in DME/Cu in the presence of a Celgard 2400 separator (conditions: $1.0 \mathrm{~mA} \mathrm{~cm}^{-2} ; 1 \mathrm{~h}$ of polarization). Short-circuit due to the formation of lithium dendrite was not observed over 300 cycles, and the CE was recorded to be $98.3 \%$ [39]. However, this low CE is not acceptable for the fabrication of practical batteries for the development of EVs.

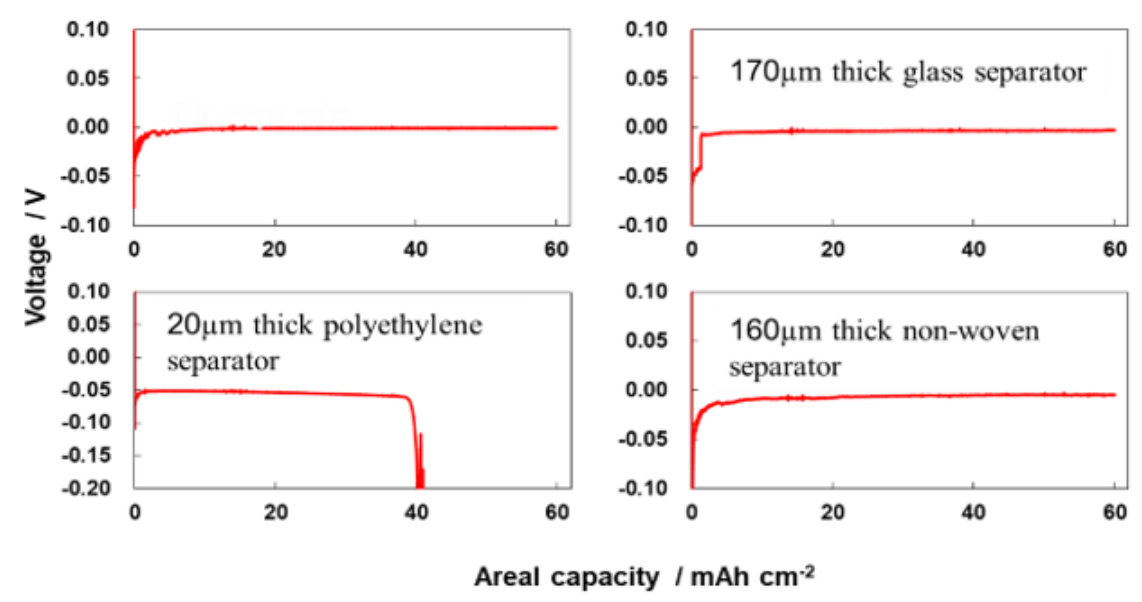

Figure 5 Polarization curves measured at $1.0 \mathrm{~mA} \mathrm{~cm}-2$ and $25^{\circ} \mathrm{C}$ for the symmetrical $\mathrm{Li} / 4 \mathrm{M} \mathrm{LiFSI}$ system in DME/Li cell under conditions of varying separators. 


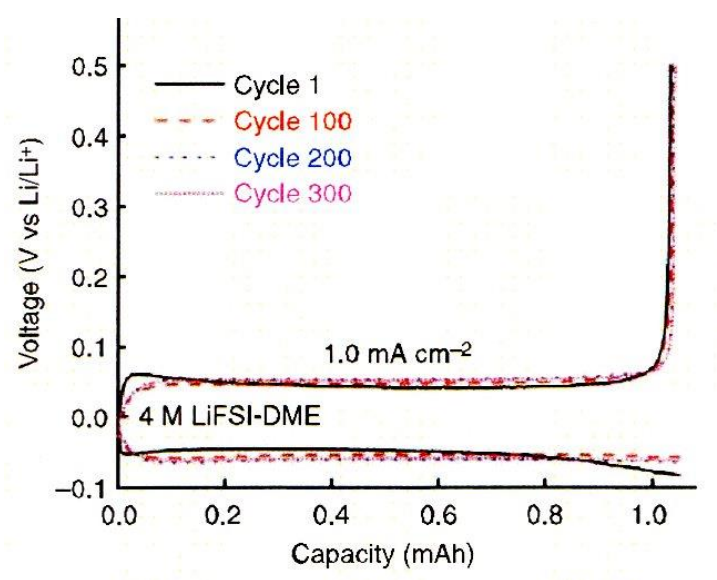

Figure 6 Cycle performance of the Li/4 M LiFSI system in DME/Cu cell with a Celgard 2400 separator at $1.0 \mathrm{~mA} \mathrm{~cm}^{-2}$ [39].

Results from the cycling tests conducted for the deposition of the lithium metal and the results obtained during stripping in the presence of the Li/1 M LiPF 6 system in EC-DEC $(1: 1 \mathrm{v} / \mathrm{v}) / \mathrm{Li}$ symmetrical cell under conditions of $1 \mathrm{~mA} \mathrm{~cm}{ }^{-2}$ and $1 \mathrm{mAh} \mathrm{cm}{ }^{-2}$ showed a continuous increase in the overpotential with cycling, completely degrading the cell at $250 \mathrm{~h}$ [40]. The cell consisting of Li/1 M LiTFSI in DOL-DMC (1:1 v/v) under conditions of $1 \mathrm{~mA} \mathrm{~cm}^{-2}$ and $1 \mathrm{mAh} \mathrm{cm}^{-2}$ exhibited a gradual increase in overpotential with cycling and a sudden drop after 100 cycles, indicating internal shortcircuiting [41]. The typical electrolytes used to fabricate lithium-ion batteries cannot be used in the presence of lithium metal anodes because they exhibit low CE and poor cycling performance during lithium deposition under conditions of stripping at high current density. The electrolyte with a high content of lithium salt (LiFSI (4 M) in DME) exhibited excellent cycling performance at $1.0 \mathrm{mAh} \mathrm{cm}^{-}$ ${ }^{2}$ (Figure 6). However, the CE was not significantly high at $98.3 \%$, and the cycling performance under conditions of a high specific area capacity could not be determined. Many researchers have studied the suppression of lithium dendrite formation under conditions of high current density in the past few decades. Table 4 summarizes the lithium metal short-circuit performance at high current densities (1-10 $\mathrm{mA} \mathrm{cm}^{-2}$ ) and the CEs for lithium metal electrodes in the presence of various nonaqueous electrolytes. Several methods, such as identifying the properties of the electrolyte [33, 39], the addition of salt to the electrolyte [27, 42], and the use of a protective layer to protect the lithium surface [43-45] and suppress the rate of lithium dendrite formation have been proposed. A lithium electrode coated with a lithium-conducting gel-type composite thin layer (thickness: $25 \mu \mathrm{m}$ ) of fine $\mathrm{Al}_{2} \mathrm{O}_{3}$ particles and polyvinylidene difluoride (PVDF)-hexafluoropropylene (HFP) with $1 \mathrm{M} \mathrm{LiClO}_{3}$ in EC-propylene carbonate (PC) did not short circuit at $10 \mathrm{~mA} \mathrm{~cm}{ }^{-2}$ and $10 \mathrm{mAh} \mathrm{cm}^{-2}$ over 10 cycles [43]. The charge/discharge efficiency of a cell with a $450 \mu \mathrm{m}$-thick-coated $\mathrm{Li}$ anode and a $\mathrm{LiCoO}_{2}$ cathode (cathode capacity: $1.6 \mathrm{mAh}$ ) at $1.0 \mathrm{~mA} \mathrm{~cm}{ }^{-2}$ was higher than $99.8 \%$ after 400 cycles. However, the CE for lithium deposition and stripping of the coated lithium electrode was not reported. Manthiram et al. [44] reported the suppression of lithium dendrite formation using a cellulose-based Kimwipe paper and Celgard composite separator at a high current density of $10 \mathrm{~mA}$ $\mathrm{cm}^{-2}$. The electrolytic system used was $\mathrm{LiCF}_{3} \mathrm{SO}_{3}$ in DOL-DME. Short-circuit by dendrite formation was not observed at $10 \mathrm{~mA} \mathrm{~cm}^{-2}$ during the $3 \mathrm{~h}$-long polarization process conducted over 60 cycles. The current density and specific area capacity recorded were attractive; however, the CE of $98.5 \%$ should be improved further for the practical application in EVs. 
Table 4 Polarization behavior of Li/non-aqueous electrolyte solution/Li cells at room temperature.

\begin{tabular}{|c|c|c|c|c|c|c|c|}
\hline \multirow[t]{2}{*}{ Li electrode } & \multirow[t]{2}{*}{ Separator } & \multirow[t]{2}{*}{ Electrolyte } & \multirow[t]{2}{*}{ CE (\%) } & \multicolumn{3}{|c|}{ Polarization } & \multirow[t]{2}{*}{ Ref } \\
\hline & & & & Current $\left(\mathrm{mA} \mathrm{cm}^{-2}\right)$ & Period (h) & cycle & \\
\hline $\mathrm{Li} / 0.8 \mathrm{Al}_{2} \mathrm{O}_{3} 0.2 \mathrm{PVDF}$ & Whatman & $\mathrm{Li} \mathrm{ClO}_{4}$ in EC-PC $(1: 1 \mathrm{v} / \mathrm{v})$ & & 10 & 1 & $>10$ & [43] \\
\hline Li metal & Celgard/KW & 1.8 $\mathrm{M} \mathrm{LiCF}_{3} \mathrm{SO}_{3}$ in DME-DOL $(1: 1 \mathrm{v} / \mathrm{v})$ & 98.5 & 10 & 3 & $>60$ & [44] \\
\hline Li/Nafion $(5 \mu \mathrm{m})$ & Celgard & $1 \mathrm{M} \mathrm{LiPF}_{6}$ in EC-DEC (1:1 v/v) & & 10 & 4 & $>250$ & [45] \\
\hline Li metal & Celgard & $4 \mathrm{M} \mathrm{LiFSI}$ & $>97$ & 10 & 0.1 & $>6000$ & [39] \\
\hline Li/carbon-fiber & Celgard & $1 \mathrm{M} \mathrm{LiTFSI}-1 \% \mathrm{LiNO}_{3}$ in DME-DOL (1:1 v/v) & & 10 & 0.1 & $>60$ & [42] \\
\hline $\mathrm{Li} / \mathrm{MoS}_{2}$ & & $1 \mathrm{M}$ LiTFSI in DOL-DME & & 10 & 0.5 & $>300$ & [46] \\
\hline $\mathrm{Li} / \mathrm{LiF} / \mathrm{GF}$ & Celgard & $1 \mathrm{M} \mathrm{LiPF}_{6}$ in EC-DEC $(1: 1 \mathrm{v} / \mathrm{v})$ & & 10 & 0.1 & $>160$ & [47] \\
\hline $\mathrm{Li}$ & ENTEK & $1 \mathrm{M} \mathrm{LiFSI}$ in DX-DME (1:2 v/v) & 98 & 5 & 1.7 & $>170$ & [33] \\
\hline Ni form & Celgard & $1 \mathrm{M} \mathrm{LiPF}_{6}$ in EC DMC- & ca. 90 & 5 & 0.2 & $>96$ & [48] \\
\hline Li & & DMC-EMC $(1: 1 \mathrm{v} / \mathrm{v})$ & & 1 & 3 & $>100$ & \\
\hline Li/LiF & & $1 \mathrm{M} \mathrm{LiPF}_{6}$ in EC-DEC & & 4 & 1 & $>60$ & [49] \\
\hline $\mathrm{Li} / \mathrm{AlPO}_{4}$ & Celgard & $1 \mathrm{M} \mathrm{LiPF}_{6}$ in EC-DMC-DEC $(1: 1: 1 \mathrm{v} / \mathrm{v})$ & & 4 & 0.5 & $>200$ & {$[50]$} \\
\hline $\mathrm{Li}$ & Celgard & $1 \mathrm{M}$ LiTFSI-12 mM InTFSI in EC-DME & $>98$ & 3 & 1 & $>100$ & [51] \\
\hline $\mathrm{Li} /$ porous C & & $1 \mathrm{M} \mathrm{LiPF}_{6}$ in EC-DEC $(1: 1 \mathrm{v} / \mathrm{v})$ & & 3 & 0.33 & $>80$ & {$[52]$} \\
\hline $\mathrm{Li} /$ carbon form & & $\begin{array}{l}1 \mathrm{M} \mathrm{LiTFSI} \mathrm{in} \mathrm{DOL-DME}(1: 1 \mathrm{v} / \mathrm{v}) \text { with } 2 \mathrm{wt} \% \\
\mathrm{LiNO}_{3}\end{array}$ & ca. 99.6 & 3 & 0.33 & $>900$ & [53] \\
\hline $\begin{array}{l}\text { Li/reduced graphene } \\
\text { oxide }\end{array}$ & & $\begin{array}{l}1 \mathrm{M} \mathrm{LiTFSI} \mathrm{in} \mathrm{DOL-DME}(1: 1 \mathrm{v} / \mathrm{v}) \text { with } 1 \mathrm{wt} \% \\
\mathrm{LiNO}_{3}\end{array}$ & & 3 & 0.33 & $>69$ & {$[54]$} \\
\hline Li/carbon nanoarray & & $\begin{array}{l}1 \mathrm{M} \mathrm{LiTFSI} \mathrm{in} \mathrm{DOL-DME}(1: 1 \mathrm{v} / \mathrm{v}) \text { with } 1 \mathrm{wt} \% \\
\mathrm{LiNO}_{3}\end{array}$ & 99 & 2 & 0.5 & $>1000$ & [55] \\
\hline $\mathrm{Li}$ & & $\begin{array}{l}1 \mathrm{M} \text { LiTFSI in DOL-DME }(1: 1 \mathrm{v} / \mathrm{v}) \text { with } 1 \mathrm{wt} \% \\
\mathrm{LiNO}_{3} 0.18 \mathrm{M} \mathrm{Li}_{2} \mathrm{~S}_{8}\end{array}$ & 99.4 & 2 & 1 & $>120$ & {$[27]$} \\
\hline $\mathrm{Li}$ & & $10 \mathrm{M}$ LiFSI in EC-DME (1:1 v/v) & 99.3 & 1 & 2 & $>120$ & [38] \\
\hline
\end{tabular}

GF: graphite fluoride. 
The protection of the lithium electrode by a lithiated NAFION thin film can effectively suppress the growth of lithium dendrite because of its high lithium-ion transport number. Figure 7 shows the cycling performance recorded during lithium deposition and stripping for a NAFION-coated lithium electrode. The electrolyte system consisted of LiPF 6 in EC-DEC, and a Celgard separator was used. Cell short -circuit was not observed at $10 \mathrm{~mA} \mathrm{~cm}{ }^{-2}$ during the $4 \mathrm{~h}$-long polarization $\left(40 \mathrm{mAh} \mathrm{cm}^{-2}\right)$ process conducted over 250 cycles. However, the CE of the lithium electrode was not reported. An electrolyte with a high content of lithium salts exhibited a high CE. Zhang et al. [39] reported that short-circuit was not observed for a Li/4 M LiFSI electrolytic system in DME/Li cell at $10 \mathrm{~mA} \mathrm{~cm}^{-2}$ when a $0.1 \mathrm{~h}$-long polarization process was conducted over 6000 cycles. The CE was estimated to be $99.1 \%$ at $0.2 \mathrm{~mA} \mathrm{~cm}^{-2}$ and $>97 \%$ at $10 \mathrm{~mA} \mathrm{~cm}^{-2}$. An electrolyte solution consisting of $10 \mathrm{M}$ of LiFSI in EC-DME showed a high CE of $99.3 \%$ at $0.2 \mathrm{~mA} \mathrm{~cm}^{-2}$, and no short-circuit was observed at $1.0 \mathrm{~mA}$ $\mathrm{cm}^{-2}$ during the $2 \mathrm{~h}$-long polarization process conducted over 1000 cycles [38]. The high CE of $99.4 \%$ for an electrolytic system consisting of LiTFSI $(1 \mathrm{M})$ and 1 wt.\% of $\mathrm{LiNO}_{3}$ and $\mathrm{Li}_{3} \mathrm{~S}_{8}(0.18 \mathrm{M})$ in DOL$\operatorname{DME}(1: 1 \mathrm{v} / \mathrm{v})$ exhibited no lithium dendrite short-circuit during 120 cycles at $2.0 \mathrm{~mA} \mathrm{~cm}{ }^{-2}$. The polarization process was conducted over $1 \mathrm{~h} \mathrm{[27].} \mathrm{However,} \mathrm{the} \mathrm{high} \mathrm{CE} \mathrm{fluctuated} \mathrm{with} \mathrm{cycling} \mathrm{at} \mathrm{a}$ high specific area capacity of $3 \mathrm{mAh} \mathrm{cm}^{-2}$ at $2 \mathrm{~mA} \mathrm{~cm}^{-2}$. Both lithium polysulfide [56] and lithium nitride [57] have been used as additives in ether-based electrolytes to suppress the growth of lithium dendrites. A synergistic effect that leads to the formation of a stable and uniform SEI [15] was observed. The long-term stability of this electrolyte at a high specific area capacity should be examined. Lithium dendrite-free electrolytes exhibiting CEs higher than 99.9\% at current densities higher than $1 \mathrm{~mA} \mathrm{~cm}-2$ and specific area capacities greater than several $\mathrm{mAh} \mathrm{cm}^{-2}$ are yet to be developed. The growth of lithium dendrites can be effectively suppressed by protecting the surface of lithium with thin lithium conducting layers composed of NAFION [45], carbon [42], $\mathrm{Al}_{2} \mathrm{O}_{3}$ [43], and $\mathrm{AlPO}_{4}$ [50]. Furthermore, three-dimensional (3D) electrodes are useful for long cycle operation because a small change in the volume is observed during charge/discharge cycles [48]. Wan et al. [53] reported a high CE of $99.6 \%$ for a 3D lithium electrode of nitrogen-doped graphitic carbon, which exhibited a high specific area capacity of $10 \mathrm{~mA} \mathrm{~h} \mathrm{~cm}{ }^{-2}$ and a high specific mass capacity of $3140 \mathrm{mAh} \mathrm{g}^{-1}$. This electrode showed no short-circuit for 900 cycles at $3 \mathrm{~mA} \mathrm{~cm}^{-2}$ and $1 \mathrm{mAh} \mathrm{cm}^{-2}$. The CE of $99.6 \%$ at $2 \mathrm{~mA} \mathrm{~cm}{ }^{-2}$ and $2 \mathrm{mAh} \mathrm{cm}{ }^{-2}$ decreased to $99.1 \%$ at $2 \mathrm{~mA} \mathrm{~cm}^{-2}$ and $8 \mathrm{mAh} \mathrm{cm}^{-2}$. The growth of lithium dendrites with this electrode under conditions of high specific area capacity should be examined for practical applications. Artificial (ex-situ) SEI films have also been studied to inhibit the formation of lithium dendrites and protect the lithium metal anode surface. An artificial SEl electroplated on lithium in DOL-DME solution containing $1 \mathrm{M}$ LiTFSI-5 wt.\% LiNO $3-0.02 \mathrm{~N} \mathrm{Li}_{2} \mathrm{~S}_{5}$ was homogeneously distributed on the lithium metal surface. This prevented the immediate reaction between the lithium metal and electrolyte [58]. An artificial SEI of $\mathrm{LiPO}_{4}$ on lithium metal showed improved cyclic performance in an electrolytic system consisting of EC-DME-DEC (1:1:1 $\mathrm{v} / \mathrm{v}$ ) and LiPF 6 (1 M) [59]. The CE for commercial lithium-ion batteries is approximately $99.9 \%$ [60, 61]. Further studies to improve the CE of the lithium electrode are required to develop non-aqueous lithium batteries for practical applications. It is a challenge to improve the CE for lithium deposition and stripping. We expect to develop a lithium battery system in the future with a high energy density ( $>500 \mathrm{Wh} \mathrm{kg}^{-2}$ ) and a CE of $99.9 \%$ for the development of EVs where short-circuiting at $5 \mathrm{~mA} \mathrm{~cm}^{-2}$ and $10 \mathrm{mAh} \mathrm{cm}^{-2}$ will be absent. 

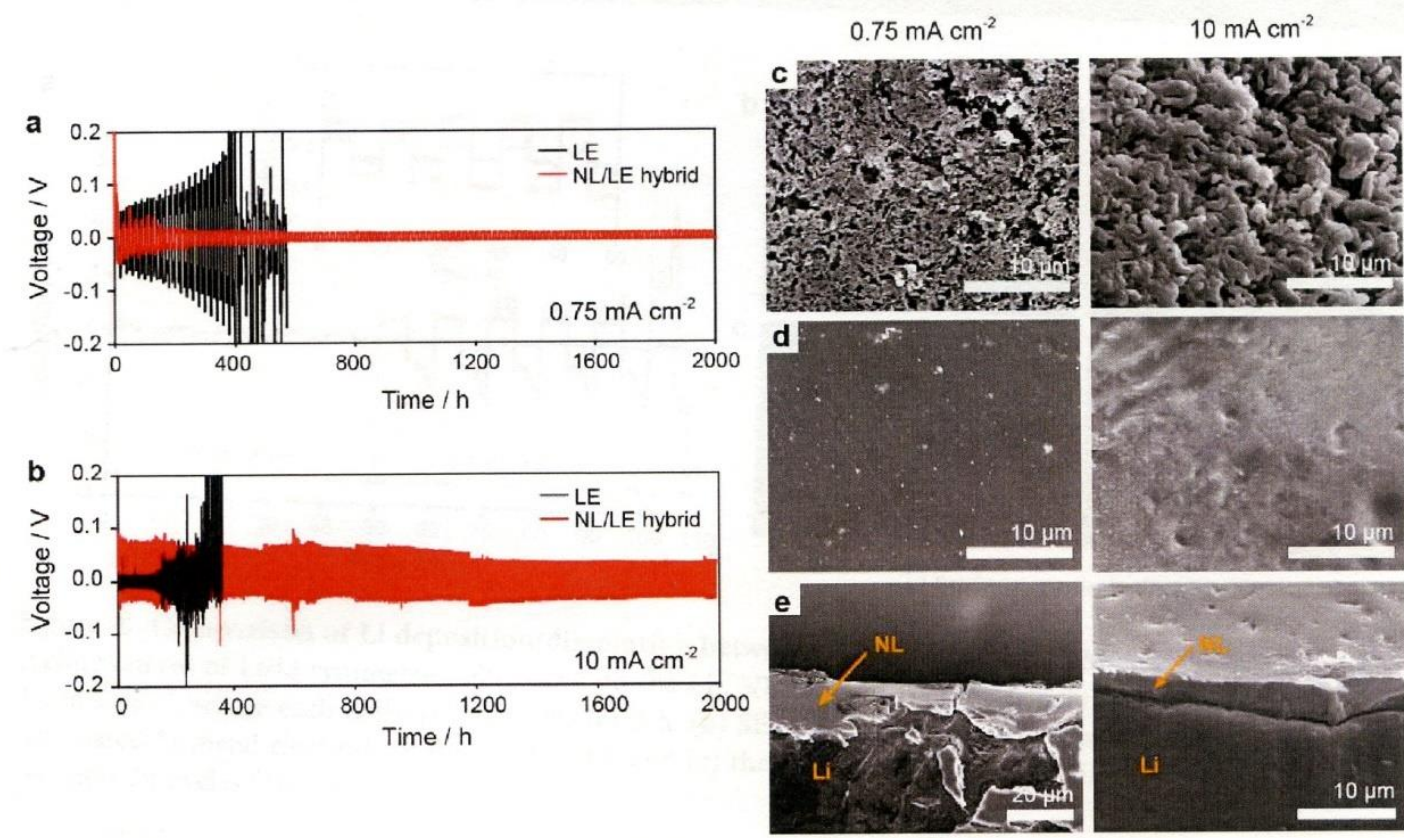

Figure 7 Comparison of $\mathrm{Li}$ deposition and stripping behavior of $\mathrm{Li} / 1 \mathrm{M} \mathrm{LiPF} 6$ in EC-DEC/Li with Celgard/Li (LE) and Li/Nafion (NL)/1 M LiPF 6 in EC-DEC with Celgard/Li (NL/LE). Cycling curves of cells (a) at $0.75 \mathrm{~mA} \mathrm{~cm}^{-2}$ for $10 \mathrm{~h}$ and (b) at $10 \mathrm{~mA} \mathrm{~cm} \mathrm{~cm}^{-2}$. SEM images of (c) the bare Li electrode after $200 \mathrm{~h}$ at $0.75 \mathrm{~mA} \mathrm{~cm}^{-2}$ and after $80 \mathrm{~h}$ at $10 \mathrm{~mA} \mathrm{~cm}^{-2}$, (d) the surface of Nafion layer (NL) on the Li metal electrode after cycling, and (e) a crosssection of the NL-coated Li metal electrode after cycling [45].

\section{Lithium Electrode in a Solid Electrolyte}

\subsection{Solid Electrolytes for Lithium Batteries}

EVs are primarily developed using lithium-ion batteries fabricated using a carbon anode, an intercalation oxide cathode, and a non-aqueous liquid electrolyte. However, the specific energy density of lithium-ion batteries is insufficient to meet the growing demand of the driving distance. The best candidates for the next-generation batteries beyond lithium-ion batteries are considered to be lithium batteries developed using a lithium metal anode and an intercalation cathode [6]. Lithium batteries with a lithium metal anode and a high-capacity cathode such as high Ni-NMC $\left(\mathrm{LiNi}_{\mathrm{x}} \mathrm{M}_{1-\mathrm{x}} \mathrm{O}_{2}, \mathrm{M}=\mathrm{Mn}\right.$ and $\left.\mathrm{Co} ; \mathrm{x}>0.6\right)$ are expected to have specific energy densities as high as 500 Wh $\mathrm{kg}^{-1}$. However, this type of battery poses a safety hazard as it contains a flammable liquid electrolyte. Lithium dendrites formed during Li plating and stripping can penetrate the separator, leading to battery short-circuiting, eventually causing fire and explosion. It is a challenge to overcome the safety hazard to develop EV batteries with practical applications. Replacement of the non-aqueous electrolyte with non-flammable and chemically/electrochemically stable solid electrolytes provides a promising solution to these safety issues [62].

Primary lithium solid electrolyte batteries consisting of Li/Lil//2-poly-2-vinylpyridine (PVP) [63] have been widely used to develop heart pacemakers, where thin lithium conducting solid electrolyte film of Lil is prepared on a lithium anode in contact with a charge-transfer complex of $I_{2}$-PVP. The reliability of this type of cell is extremely high, making it suitable for use in pacemakers. However, 
this type of cell cannot be recharged, and the cell resistance increases with the discharge period because the Lil reaction product is deposited on the cathode electrode. The $\mathrm{Li} / \mathrm{Lil} / \mathrm{I}_{2}-\mathrm{PVP}$ cell contains a specially designed cathode. The lithium-ion conductivity of Lil is as low as $5.5 \times 10^{-7} \mathrm{~S} \mathrm{~cm}^{-}$ ${ }^{1}$ at $30^{\circ} \mathrm{C}$ [64] and the discharge current density of the Li/Lil// $\mathrm{L}_{2} \mathrm{PVP}$ cell is approximately $20 \mu \mathrm{A} \mathrm{cm}{ }^{-}$ 2. The first rechargeable solid electrolyte lithium battery was reported by Gauthier et al. in 1985 [65], which consisted of lithium conducting PEO-based polymer electrolyte of $\mathrm{PEO}_{8} \mathrm{LiClO}_{4}$ (or $\mathrm{LiCF}_{3} \mathrm{SO}_{2}$ ) and $a \mathrm{TiS}_{2}$ (or $\mathrm{V}_{6} \mathrm{O}_{13}$ ) cathode. The lithium-ion conductivity of the polymer electrolyte at room temperature was as low as $10^{-7} \mathrm{~S} \mathrm{~cm}^{-1}$. Therefore, the cell was operated above $65^{\circ} \mathrm{C}$. The cell with the $\mathrm{TiS}_{2}$ cathode exhibited good cycling performance. The cell was cycled at $0.5 \mathrm{~mA} \mathrm{~cm}{ }^{-2}$ for discharge and $0.125 \mathrm{~mA} \mathrm{~cm}^{-2}$ to charge at $100{ }^{\circ} \mathrm{C}$ over 16 cycles. Polymer electrolyte batteries have been developed on a large scale by Hydro Quebec and $3 \mathrm{M}$ for EV applications under contract (the United States Advanced Battery Consortium [USABC]) since 1993 [66]. An energy density of 155 Wh kg-1 (target: 300), a power density of $315 \mathrm{~W} \mathrm{~kg}^{-1}$ (target: 300$)$, and cycle life of 600 (target: 1000) were established for the $38.8 \mathrm{kWh}$ module in 1998. However, the development of lithium polymer batteries for EVs has not yet been realized as safety issues are yet to be addressed. Most of the polymer electrolytes partially suppress the formation of dendrites at the interface between the lithium electrode and the polymer electrolyte [67]. At present, polymer, inorganic, and inorganic/polymer composite electrolytes have been studied as solid electrolytes for the fabrication of lithium batteries. In this short review, we will focus on the formation of lithium dendrites at the interface of the lithium metal electrode in the presence of solid electrolytes.

Various types of high lithium-ion conducting solid electrolytes have been reported in the last three decades. Table 5 summarizes the properties and types of the solid electrolytes that exhibit high room temperature lithium-ion conductivity. The highest lithium-ion conductivity of $2.5 \times 10^{-2}$ $\mathrm{S} \mathrm{cm}^{-1}$ at $25{ }^{\circ} \mathrm{C}$ for $\mathrm{Li}_{9.45} \mathrm{Si}_{1.74} \mathrm{P}_{1.44} \mathrm{~S}_{11.7} \mathrm{Cl}_{0.3}$ was reported by Kanno et al. [68]. The lithium-ion conductivity was higher than $1.66 \times 10^{-2} \mathrm{~S} \mathrm{~cm}^{-2}$ (exhibited by the conventional non-aqueous liquid electrolyte composed of $\mathrm{LiPF}_{6}$ [1 M] in EC-DME [1:1 v/v]) [69]. The solid sulfide lithium-ion conductors are stable when in contact with the lithium metal. However, they are unstable when in contact with the atmosphere. While oxide lithium-ion conductors such as the NASICON-type and perovskite-type oxides are more stable in the atmosphere, they are unstable when in contact with the lithium metal. The garnet-type oxide lithium-ion conductors are stable in contact with lithium metal but react with water and oxygen in the air, gradually decreasing the lithium-ion conductivity. New types of solid lithium-ion conductors, such as $\mathrm{Li}_{3} \mathrm{OCl} \mathrm{C}_{0.5} \mathrm{Br}_{0.5}$ [70], $0.7 \mathrm{Li}\left(\mathrm{CB}_{9} \mathrm{H}_{10}\right)-0.3 \mathrm{Li}\left(\mathrm{CB}_{11} \mathrm{H}_{12}\right)$ [71], and $\mathrm{Li}_{3} \mathrm{YBr}$ [72], have been reported. The room temperature lithium-ion conductivities of these conductors are higher than $10^{-3} \mathrm{~S} \mathrm{~cm}^{-1}$ or approximately $10^{-3} \mathrm{~S} \mathrm{~cm}^{-1}$. They are stable in contact with lithium metal and should be handled in a glove box because they are considerably hygroscopic. Polymer electrolytes are attractive electrolytes that can be used to develop lithium batteries because they are more flexible than liquid organic electrolytes. The processing cost and flammability of the polymer electrolytes are also lower than those of the liquid organic electrolytes [73]. The room temperature conductivities of the conventional polymer electrolytes are considerably lower than those of the liquid electrolytes. A typical PEO-based polymer electrolyte composed of $\mathrm{PEO}_{8}$ LiTFSI exhibits a conductivity of $1 \times 10^{-5} \mathrm{~S} \mathrm{~cm}^{-1}$ at $25^{\circ} \mathrm{C}$ and transforms to a high-temperature phase at around $60^{\circ} \mathrm{C}$, exhibiting high ion conductivity of approximately $10^{-3} \mathrm{~S} \mathrm{~cm}^{-1}$ [74]. In the past few decades, high room temperature lithium-ion conductivity polymer electrolytes have been extensively developed by several researchers [75]. However, there are presently no polymer 
electrolytes that exhibit room temperature lithium-ion conductivities higher than $10^{-3} \mathrm{~S} \mathrm{~cm}^{-1}$. The inorganic/polymer composite electrolytes exhibited high lithium-ion conductivity, excellent mechanical strength, and high thermal and chemical stability over those of the pristine polymer electrolytes [76, 77]. Gel-type polymer electrolytes were proposed by Abraham and Alamgir in 1990, which were isolated as dimensionally stable, free-standing films [78]. The gel-type polymer electrolytes contain liquid electrolytes. Therefore, the behavior at the lithium metal electrode-geltype polymer electrolyte interface is similar to the behavior of a system composed of a lithium metal electrode and a liquid electrolyte [79]. Figure 8 shows the Arrhenius plots of the ionic conductivities of the various solid electrolytes. One advantage of solid electrolytes is that they can be used over a wide range of temperatures, unlike conventional liquid electrolytes.

Table 5 Room temperature ion conductivities of various types of solid electrolytes.

\begin{tabular}{|c|c|c|c|c|c|}
\hline Type & Electrolyte & $\begin{array}{l}\text { Conductivity } \\
\text { at } 25\left(\mathrm{~S} \mathrm{~cm}^{-1}\right)\end{array}$ & $\begin{array}{l}\text { Stability } \\
\text { in air }\end{array}$ & with Li & Ref. \\
\hline Thio-LISICON & $\mathrm{Li}_{10} \mathrm{GeP}_{2} \mathrm{~S}_{12}$ & $1.2 \times 10^{-2}$ & unstable & stable & [80] \\
\hline Thio-LISICON & $\mathrm{Li}_{9.45} \mathrm{Si}_{1.74} \mathrm{P}_{1.44} \mathrm{~S}_{11.7} \mathrm{Cl}_{0.3}$ & $2.5 \times 10^{-2}$ & unstable & stable & [68] \\
\hline Argyrodite & $\mathrm{Li}_{6} \mathrm{PS}_{5} \mathrm{Cl}_{0.3} \mathrm{~F}_{0.7}$ & $5 \times 10^{-4}$ & unstable & stable & [81] \\
\hline NASICON & $\mathrm{Li}_{1.3} \mathrm{Al}_{0.3} \mathrm{Ti}_{1.7}\left(\mathrm{PO}_{4}\right)_{3}$ & $7 \times 10^{-4}$ & stable & unstable & [82] \\
\hline NASICON & $\mathrm{Li}_{1.4} \mathrm{Al}_{0.4} \mathrm{Ge}_{0.2} \mathrm{Ti}_{1.4}\left(\mathrm{PO}_{4}\right)_{3}$ & $1.29 \times 10^{-3}$ & stable & unstable & [83] \\
\hline Garnet & $\mathrm{Li}_{7} \mathrm{La}_{3} \mathrm{Zr}_{2} \mathrm{O}_{12}$ & $7.7 \times 10^{-4}$ & unstable & stable & [84] \\
\hline Garnet & $\mathrm{Li}_{6.55} \mathrm{Ga}_{0.15} \mathrm{La}_{3} \mathrm{Zr}_{2} \mathrm{O}_{12}$ & $2,06 \times 10^{-3}$ & unstable & stable & [85] \\
\hline Perovskite & $\mathrm{Li}_{0.34} \mathrm{La}_{0.31} \mathrm{TiO}_{2.94}$ & $1.0 \times 10^{-3}$ & stable & unstable & [86] \\
\hline Anti-perovskite & $\mathrm{Li}_{3} \mathrm{OCl}_{0.5} \mathrm{Br}_{0.5}$ & $1.94 \times 10^{-3}$ & unstable & stable & [70] \\
\hline Layer & $\mathrm{Li}_{3} \mathrm{~N}$ & $6 \times 10^{-3}$ & unstable & stable & [87] \\
\hline Hydride & 0.7Li $\left(\mathrm{CB}_{9} \mathrm{H}_{10}\right)-0.3 \mathrm{Li}\left(\mathrm{CB}_{11} \mathrm{H}_{12}\right)$ & $6.7 \times 10^{-3}$ & unstable & stable & [71] \\
\hline Halide & $\mathrm{Li}_{3} \mathrm{YB}$ & $7.2 \times 10^{-4}$ & unstable & stable & [72] \\
\hline Polymer & $\mathrm{PEO}_{8} \mathrm{LiTFSI}$ & $1.0 \times 10^{-5}$ & unstable & stable & [74] \\
\hline Polymer & Polyimide/PEO/LiTFS & $2.3 \times 10^{-4}$ & unstable & stable & [88] \\
\hline Gel-polymer & $\begin{array}{l}\text { PVDF-HFP-1M LiPF } 6 \text { in EC-DEC } \\
(1: 1 \mathrm{v} / \mathrm{v})\end{array}$ & $3.4 \times 10^{-3}$ & unstable & stable & [89] \\
\hline Composite & $\begin{array}{l}20 \text { wt\% } \% \mathrm{Li}_{3 / 8} \mathrm{Sr}_{7 / 16} \mathrm{Ta}_{3 / 4} \mathrm{Zr}_{1 / 4} \mathrm{O}_{3-} \\
80 \text { wt\% } \mathrm{PEO}_{10} \mathrm{LiTFSI}\end{array}$ & $5.4 \times 10^{-5}$ & unstable & stable & [76] \\
\hline Composite & $\begin{array}{l}25 \text { wt\% } \mathrm{LiZr}_{2}\left(\mathrm{PO}_{4}\right)_{3-75} \text { wt\% } \\
\mathrm{PEO}_{10} \mathrm{LiTFSI}\end{array}$ & $1.2 \times 10^{-4}$ & unstable & stable & [77] \\
\hline Composite & $\begin{array}{l}\text { nanofiber } \mathrm{Li}_{6.4} \mathrm{La}_{3} \mathrm{Zr}_{2} \mathrm{Al}_{0.2} \mathrm{O}_{12}- \\
\text { PEO-LiTFSI }\end{array}$ & $2.5 \times 10^{-4}$ & unstable & stable & [90] \\
\hline
\end{tabular}

PVDF: poly(vinylidene fluoride); HFP: hexafluoropropylene. 


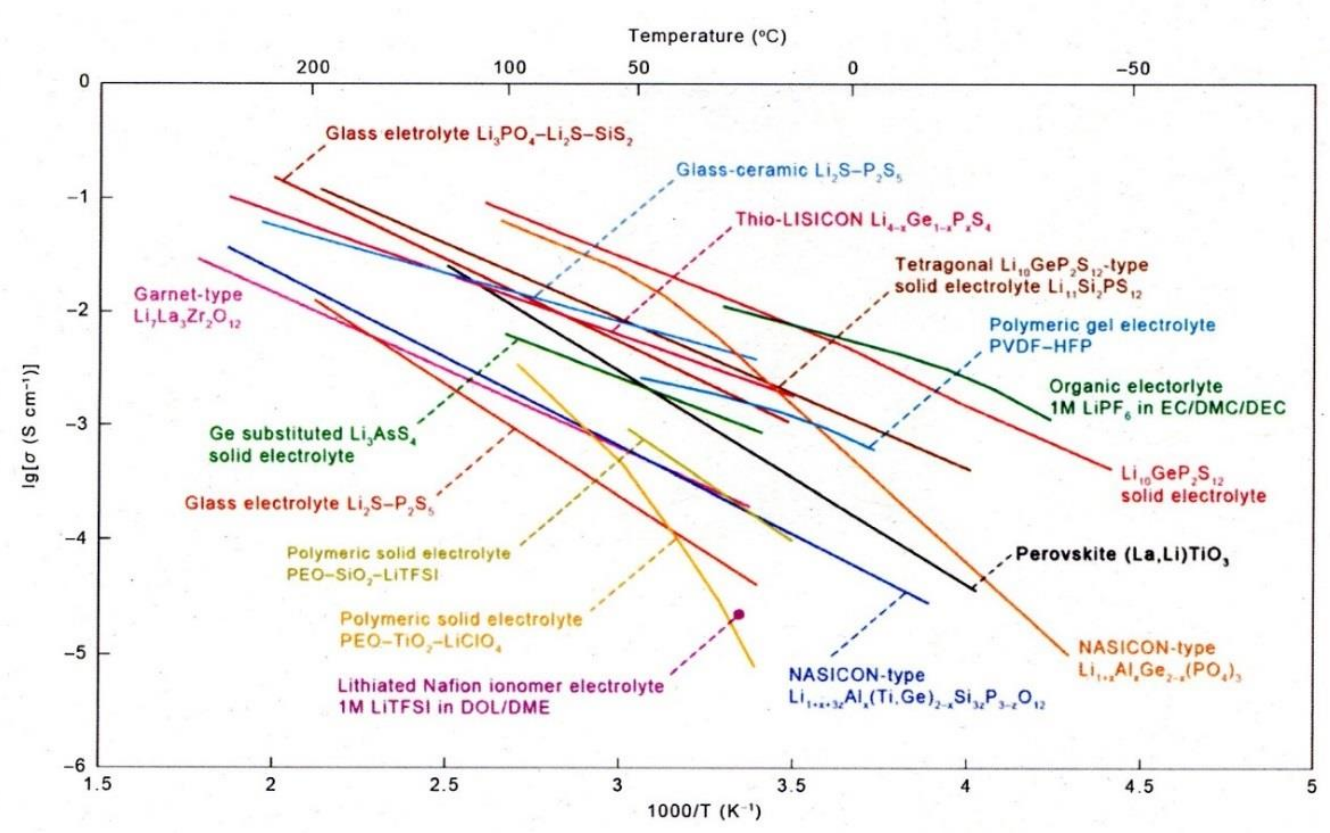

Figure 8 Arrhenius plots of the ionic conductivities of various solid electrolytes [91].

\subsection{Lithium Dendrite Formation in Solid Polymer Electrolytes}

Polymer electrolytes are attractive for the large-scale development of batteries as they are easy to prepare, exhibit particularly large thin films, and have lower flammability (compared to liquid electrolytes). Imanishi and co-workers reported excellent lithium deposition and stripping cycle performance for a PEO-based electrolyte at $0.3 \mathrm{~mA} \mathrm{~cm}^{-2}$ for a $30 \mathrm{~h}$-polarization method conducted at $60{ }^{\circ} \mathrm{C}$ (Figure 9). Under these conditions, lithium dendrite short-circuit was not observed for an $1800 \mathrm{~h}$ cycling process [16]. The $\mathrm{SiO}_{2}$ oxide filler and $\mathrm{N}$-methyl-N-propylpiperidnium bis(trifluoromethanesulfonyl)imide ionic liquid could effectively improve the conductivity and reduce the interface resistance between the lithium electrode and polymer electrolyte. The composite polymer electrolyte exhibited excellent cycle performance for lithium deposition and stripping at $0.3 \mathrm{~mA} \mathrm{~cm}^{-2}$. A high specific area capacity of $9 \mathrm{mAh} \mathrm{cm} \mathrm{m}^{-2}$ was recorded at $60^{\circ} \mathrm{C}$. However, the room temperature conductivity of the polymer electrolyte was only $3.68 \times 10^{-5} \mathrm{~S} \mathrm{~cm}^{-1}$. The onset time for the formation of lithium dendrites for a typical polymer electrolyte was longer than that of a conventional liquid electrolyte. The formation of lithium dendrites should be suppressed at higher current densities. For example, $\mathrm{PEO}_{18} \mathrm{LiTFSI}$ at $60^{\circ} \mathrm{C}$ exhibited an onset time of $15 \mathrm{~h}$ at 0.3 $\mathrm{mA} \mathrm{cm}{ }^{-2}\left(4.5 \mathrm{mAh} \mathrm{cm}^{-2}\right)$ and $125 \mathrm{~h}$ at $0.1 \mathrm{~mA} \mathrm{~cm}{ }^{-2}\left(12.5 \mathrm{mAh} \mathrm{cm}{ }^{-2}\right)$ [67]. A lithium-stable lithiumconducting solid electrolyte, such as $\mathrm{Li}_{7} \mathrm{La}_{3} \mathrm{Zr}_{2} \mathrm{O}_{12}$, an ionic liquid, and a liquid electrolyte were added to the polymer electrolytes to improve the room temperature conductivity and suppress the formation of lithium dendrites. Table 6 summarizes the electrical conductivities, cycle performance, and cell resistance of Li/polymer-based electrolyte/Li cells. A typical polymer electrolyte composed of $\mathrm{PEO}_{18}$ LiTFSI cannot pass a high current density at room temperature because its ionic conductivity is significantly low, and the interface resistance between the lithium electrode and electrolyte is high. The ionic conductivity of PEO 18 LiTFSI $\left(5.13 \times 10^{-6} \mathrm{~S} \mathrm{~cm}^{-1}\right.$ at $\left.25^{\circ} \mathrm{C}\right)$ increased to $4.1 \times 10^{-4} \mathrm{~S} \mathrm{~cm}^{-}$ ${ }^{1}$ at $60^{\circ} \mathrm{C}$. Lithium dendrite short-circuiting was observed at $1.0 \mathrm{~mA} \mathrm{~cm}{ }^{-2}$ when the polarization process was conducted for $15 \mathrm{~h}$ at $60{ }^{\circ} \mathrm{C}$ [92]. A composite film composed of lithium-stable and flexible PEO and a garnet type solid electrolyte is attractive as a lithium battery electrolyte; however, 
the room temperature conductivity is not adequately high. So, a cell with such a polymer electrolyte would need to be operated at a high temperature [93]. Fu et al. [90] reported that a flexible composite solid electrolyte consisting of a nanofiber of $\mathrm{Li}_{6.4} \mathrm{Al}_{0.2} \mathrm{La}_{3} \mathrm{Zr}_{2} \mathrm{O}_{12}$ membrane with a PEObased polymer electrolyte could operate at room temperature. The polymer electrolyte content was $~ 20$ wt.\% and the room temperature conductivity was $2.5 \times 10^{-4} \mathrm{~S} \mathrm{~cm}^{-1}$. No lithium dendrite short-circuit was observed at $0.5 \mathrm{~mA} \mathrm{~cm}^{-2}$ during the $0.5 \mathrm{~h}$-long polarization process over 500 cycles. Although this result is attractive, the cycle performance should be examined under conditions of higher specific area capacity. Another approach to prepare a room temperature polymer electrolyte involves the use of a gel-type polymer electrolyte [78]. Gel-type polymer electrolytes consist of a liquid lithium-ion conducting electrolyte and a polymer network such as PEO, poly(acrylonitrile) (PAN), or poly(vinylidene fluoride-co-hexafluoropropylene) (PVDF-HFB). The ionic conductivity of a gel-type polymer electrolyte is comparable to that of a liquid electrolyte because the liquid electrolyte content is as high as 70-80 wt.\%. A gel-type polymer electrolyte composed of PVDF-HFB containing boron nitride (BN) nanoflakes exhibited excellent lithium plating and stripping cycle performance at room temperature [94]. At room temperature, no short-circuit was observed for the gel-type polymer electrolyte at $1.0 \mathrm{~mA} \mathrm{~cm}{ }^{-2}$ during the $3 \mathrm{~h}$-long polarization process carried over 320 cycles. The Li/1 M LiTFSI in EC-DEC/Li cell with a Celgard separator showed a short-circuit at $1.0 \mathrm{~mA} \mathrm{~cm}^{-2}$ during the $3 \mathrm{~h}$-long polarization process carried over approximately 60 cycles. An advantage of the gel-type polymer electrolyte is that a self-standing electrolyte film can be prepared that exhibits a high lithium-ion conductivity at room temperature. However, the flammability of this electrolyte is similar to that of a non-aqueous liquid electrolyte.

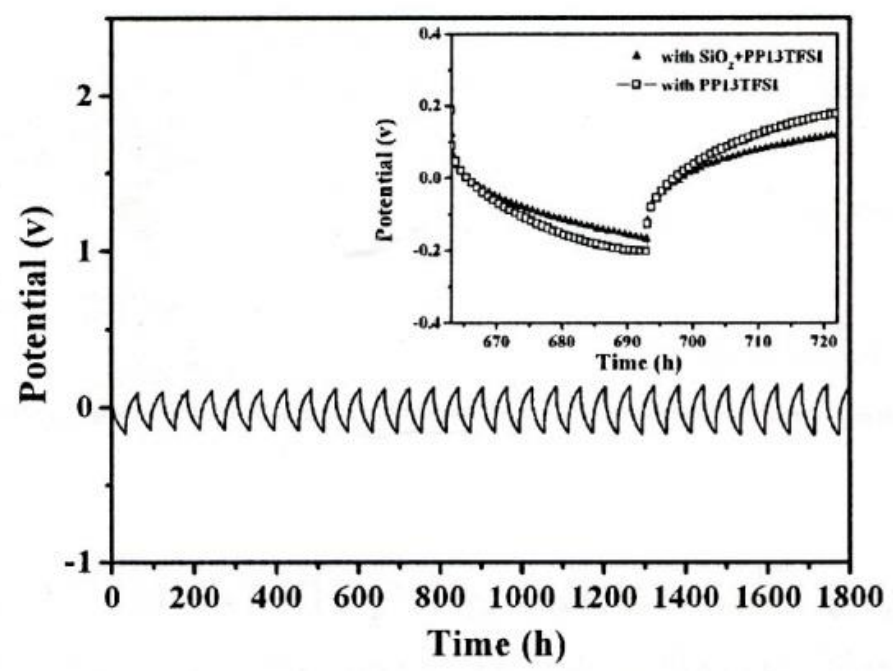

Figure 9 Cycle performance of the Li/PEO ${ }_{18} \mathrm{LiTFSI}_{\mathrm{SiO}}-\mathrm{PP} 13 \mathrm{TFSI} / \mathrm{Li}$ cell at $60{ }^{\circ} \mathrm{C}$ and 0.3 $\mathrm{mA} \mathrm{cm}{ }^{-2}$ (time: $30 \mathrm{~h}$ ). The inset shows a comparison of the $11^{\text {th }}$ cycle of $\mathrm{Li} / \mathrm{PEO}_{18}-\mathrm{SiO}_{2}-$ PP13TFSI/Li and Li/PEO 18 -PP13TFSI/Li [16].

Table 6 Polarization behavior of the Li/polymer electrolyte/Li system. 


\begin{tabular}{|c|c|c|c|c|c|c|c|}
\hline & $\begin{array}{l}\text { Operation } \\
\text { temper- } \\
\text { ature } \\
\left({ }^{\circ} \mathrm{C}\right)\end{array}$ & $\begin{array}{l}\text { Conductivity } \\
\left(\mathrm{S} \mathrm{cm}^{-1}\right)\end{array}$ & $\begin{array}{l}\text { Cell } \\
\text { resistance } \\
\left(\Omega \mathrm{cm}^{2}\right)\end{array}$ & $\begin{array}{l}\text { Current } \\
(\mathrm{mA} \\
\left.\mathrm{cm}^{-2}\right)\end{array}$ & $\begin{array}{l}\text { Period } \\
\text { (h) }\end{array}$ & Cycle & \\
\hline PEO $_{18}$ LITFSI & 60 & $4.1 \times 10^{-4}$ & 400 & 1.0 & 15 & 1 & [92] \\
\hline $\mathrm{PEO}_{18} \mathrm{Li} \quad$ TFSI-1.44 & 60 & $7.64 \times 10^{-4}$ & 60 & 0.3 & 30 & $>30$ & [16] \\
\hline $\begin{array}{l}\text { PP13TFSI-10 wt\% } \\
\mathrm{SiO}_{2}\end{array}$ & & & & & & & \\
\hline $\begin{array}{l}\text { PEO }_{18} \text { TFSI- } 80 \quad \text { wt. } \% \\
\text { nanofiber }\end{array}$ & 25 & $2.5 \times 10^{-4}$ & 20 & 0.5 & 0.5 & $>500$ & [90] \\
\hline $\begin{array}{l}\mathrm{Li}_{6.4} \mathrm{Al}_{0.2} \mathrm{La}_{3} \mathrm{Zr}_{2} \mathrm{O}_{12} \\
\text { membrane }\end{array}$ & & & & & & & \\
\hline 75 wt\%PEO ${ }_{10}$ LiTFSI & 40 & $3.5 \times 10^{-4}$ & 900 & 0.3 & 0.17 & $>300$ & [77] \\
\hline $25 w t \% \operatorname{LiZr}_{2}\left(\mathrm{PO}_{4}\right)_{3}$ & & & & & & & \\
\hline $\begin{array}{rrr}90 & \text { wt\% } & \text { PEO }_{8} \text { LiTFSI- } \\
10 & & \text { wt\% }\end{array}$ & 55 & $5.6 \times 10^{-4}$ & 100 & 0.5 & 1 & $>670$ & [93] \\
\hline $\mathrm{Li}_{6.4} \mathrm{La}_{3} \mathrm{Zr}_{1.4} \mathrm{Ta}_{0.6} \mathrm{O}_{12}$ & & & & & & & \\
\hline $\begin{array}{l}\text { PVDF-HFB-1 M LiTFSI } \\
\text { in EC-DEC with } 0.5 \\
\text { wt\% BN }\end{array}$ & 25 & $8 \times 10^{-4}$ & 150 & 1.0 & 3 & 320 & [94] \\
\hline
\end{tabular}

\subsection{Formation of Lithium Dendrites in Inorganic Solid Electrolytes}

Table 5 lists the various types of inorganic lithium-ion conducting solid electrolytes that have been reported to date. Some of the reported electrolytes have been examined as electrolytes for the development of lithium batteries $[8,95]$. The most important requirement for the development of inorganic lithium-ion conducting solid electrolytes for the fabrication of all-solid lithium batteries is that they should be stable in contact with lithium. Solid electrolytes that contain a transition metal, such as $\mathrm{Li}_{1.3} \mathrm{Al}_{0.3} \mathrm{Ti}_{1.7}\left(\mathrm{PO}_{4}\right)_{3}$ and $\mathrm{Li}_{0.34} \mathrm{La}_{0.31} \mathrm{TiO}_{2.94}$, are unstable in contact with lithium metal. The instability can be attributed to the reduction of the transition metal in the presence of lithium [96, 97]. These lithium-unstable solid electrolytes have been used as separators for aqueous lithium-air batteries as they are stable in water [98, 99]. A lithium-stable polymer electrolyte and a nonaqueous liquid electrolyte were used as a buffer layer between the lithium anode and the waterstable solid electrolyte. Thio-LISICON, argyrodite, garnet-type, and halide solid lithium conductors are stable in contact with lithium metal. The other requirement for developing a solid lithium-ion conductor as an electrolyte in batteries is that lithium dendrites should not form during the processes of lithium deposition and stripping. According to Monroe and Newman, the shear modulus of solid electrolyte must be approximately twice that of metallic lithium (4.2 GPa) to suppress the formation of lithium dendrites [100]. The shear modulus of the garnet-type $\mathrm{Li}_{6.28} \mathrm{La}_{3} \mathrm{Zr}_{2} \mathrm{Al}_{0.24} \mathrm{O}_{12}$ was reported to be $61 \mathrm{GPa}$ [101]. Imanishi and co-workers reported the shortcircuit of a Li/garnet-type solid electrolyte/Li cell. This could be attributed to lithium dendrite formation and propagation at $0.5 \mathrm{~mA} \mathrm{~cm}^{-2}$ and $25{ }^{\circ} \mathrm{C}$ for a short period of polarization [102-104], as shown in Figure 10. The short-circuiting of the Li/garnet-type solid electrolyte/Li cell resulted from the growth of lithium dendrites through the grain boundaries [103]. Suzuki et al. reported no 
short-circuit due to lithium dendrite formation for a Li/garnet-type solid electrolyte/Li cell in the presence of a quasi-single crystal solid electrolyte (no grain boundaries) operated at $0.5 \mathrm{~mA} \mathrm{~cm}^{-2}$ and room temperature [105].

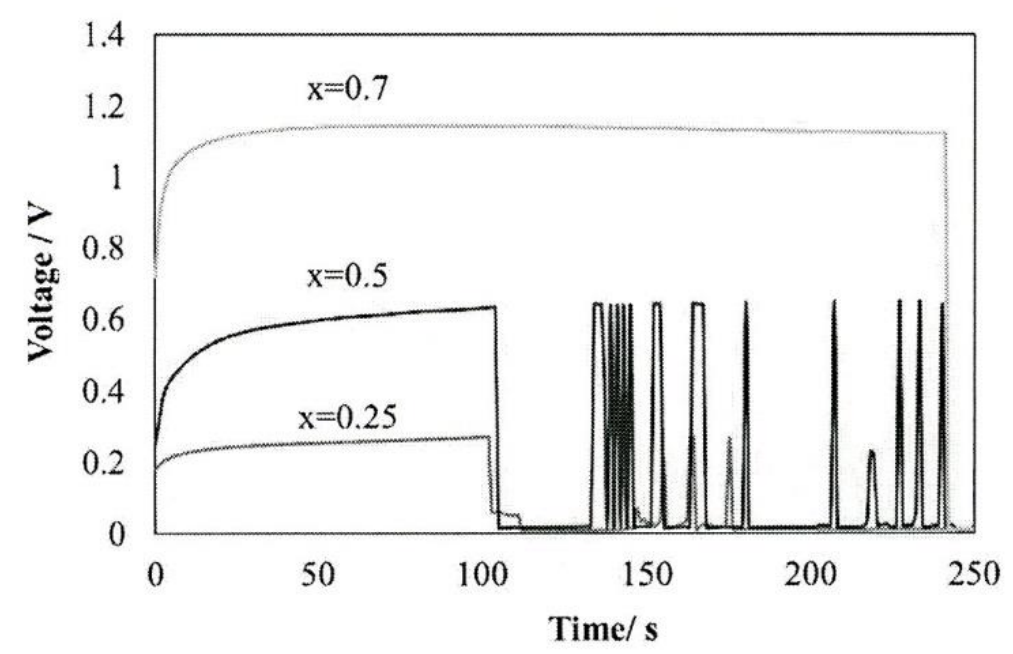

Figure 10 Cell voltage vs. polarization period curves for $\mathrm{Li} / \mathrm{Li}_{7-x} \mathrm{La}_{3} \mathrm{Zr}_{2-\mathrm{x}} \mathrm{Ta}_{x} \mathrm{O}_{12}$ at $0.5 \mathrm{~mA}$ $\mathrm{cm}^{-2}$ and $25{ }^{\circ} \mathrm{C}$ [104].

The dendrite short-circuit period is dependent on the current density. Table 7 shows the polarization behavior of the Li/lithium-ion conducting solid electrolyte/Li cells. At room temperature, almost all the solid electrolytes exhibit high interface resistance between the solid electrolyte and the lithium electrode and the polarization behavior has been reported at a low current density of less than $1 \mathrm{~mA} \mathrm{~cm}^{-2}$ (exception: $\mathrm{Li}_{6} \mathrm{PS}_{5} \mathrm{Cl}_{0.3} \mathrm{~F}_{0.7}$ ) [81]. The lithium-ion conductivity of this electrolyte was recorded to be $5.2 \times 10^{-4} \mathrm{~S} \mathrm{~cm}^{-1}$ at $25^{\circ} \mathrm{C}$, which was lower than that of $\mathrm{Li}_{6} \mathrm{PS}_{5} \mathrm{Cl}$ at $3.1 \times 10^{-3} \mathrm{~S}$ $\mathrm{cm}^{-1}$. However, the cell resistance of $\mathrm{Li} / \mathrm{Li}_{6} \mathrm{PS}_{5} \mathrm{Cl}_{0.3} \mathrm{~F}_{0.7} / \mathrm{Li}$ was as low as $130 \Omega$. The lithium symmetrical cell underwent ultrastable Li plating and stripping over $250 \mathrm{~h}$ under the conditions of a high current density of $6.37 \mathrm{~mA} \mathrm{~cm}^{-2}$ (polarization time: $0.78 \mathrm{~h} ; 5 \mathrm{mAh} \mathrm{cm}^{-2}$; Figure 11). The cell was pre-treated with lithium (plating and stripping for $\sim 200 \mathrm{~h}$ at $0.127 \mathrm{~mA} \mathrm{~cm}{ }^{-2}$ and $0.1 \mathrm{mAh} \mathrm{cm}^{-}$ ${ }^{2}$ ). The high performance could be explained by the formation of a highly dense and sheet-like surface morphology. A symmetrical lithium cell with a high lithium-ion conducting solid electrolyte of LISICON-type $\mathrm{Li}_{10} \mathrm{GeP}_{2} \mathrm{~S}_{12}$ short-circuited at $0.25 \mathrm{~mA} \mathrm{~cm}^{-2}$ (polarization time: $1 \mathrm{~h}$; 5 cycles) [106]. The performance of the lithium electrode was improved using a lithium metal/graphite composite electrode and by applying pressure. Garnet-type $\mathrm{Li}_{7} \mathrm{La}_{3} \mathrm{Zr}_{2} \mathrm{O}_{12}$ is an attractive candidate for the solid electrolyte with a lithium anode because of its stability with both lithium metal and water. Sakamoto and co-workers [107] reported that no short-circuit was observed for a $\mathrm{Li}^{\mathrm{L}} \mathrm{Li} \mathrm{i}_{6.75} \mathrm{Al}_{0.25} \mathrm{La}_{3} \mathrm{Zr}_{2} \mathrm{O}_{12} / \mathrm{Li}$ cell at $0.2 \mathrm{~mA} \mathrm{~cm}-2$ when the polarization process was conducted over $2 \mathrm{~h}$ over 100 cycles. $\mathrm{Li}_{6.75} \mathrm{Al}_{0.25} \mathrm{La}_{3} \mathrm{Zr}_{2} \mathrm{O}_{12}$ was prepared by hot-pressing at $62 \mathrm{MPa}$ and the surface was polished using 400 grit $\mathrm{SiC}$ sandpaper. Composites of the garnet-type solid electrolyte and polymer electrolyte have been proposed because of their flexibility. The composite consisting of $80 \mathrm{wt}$.\% $\mathrm{Li}_{6.4} \mathrm{Al}_{0.2} \mathrm{La}_{3} \mathrm{Zr}_{2} \mathrm{O}_{12}$ nanofiber film and 20 wt.\% PEO ${ }_{18}$ LiTFSI showed excellent lithium deposition and stripping cyclic performance at $0.5 \mathrm{~mA} \mathrm{~cm}{ }^{-2}$ when the polarization time was $0.5 \mathrm{~h}$ (number of cycles: 350; room temperature) [90]. The cell resistance of the $\mathrm{Li} / 0.7 \mathrm{Li}\left(\mathrm{CB}_{9} \mathrm{H}_{10}\right) 0.3\left(\mathrm{CB}_{11} \mathrm{H}_{12}\right) / \mathrm{Li}$ cell with a new type high lithium-ion conducting solid electrolyte was low and excellent cycle performance was achieved 
at $0.2 \mathrm{~mA} \mathrm{~cm}^{-2}$ [108]. The lithium deposition and stripping performances of a $\mathrm{Li} / \mathrm{Li}_{3} \mathrm{PS}_{4} / \mathrm{Li}$ cell were improved using an In-Li electrode. A cell fabricated using a Li electrode was short-circuited at 0.3 $\mathrm{mA} \mathrm{cm}{ }^{-2}$ over 23 cycles when the polarization time was $2 \mathrm{~h}$, whereas a cell with $1.27 \mathrm{ln}$-Li did not short-circuit at $1.0 \mathrm{~mA} \mathrm{~cm}^{-2}$ (polarization time: $1 \mathrm{~h}$; number of cycles: 100) [109].

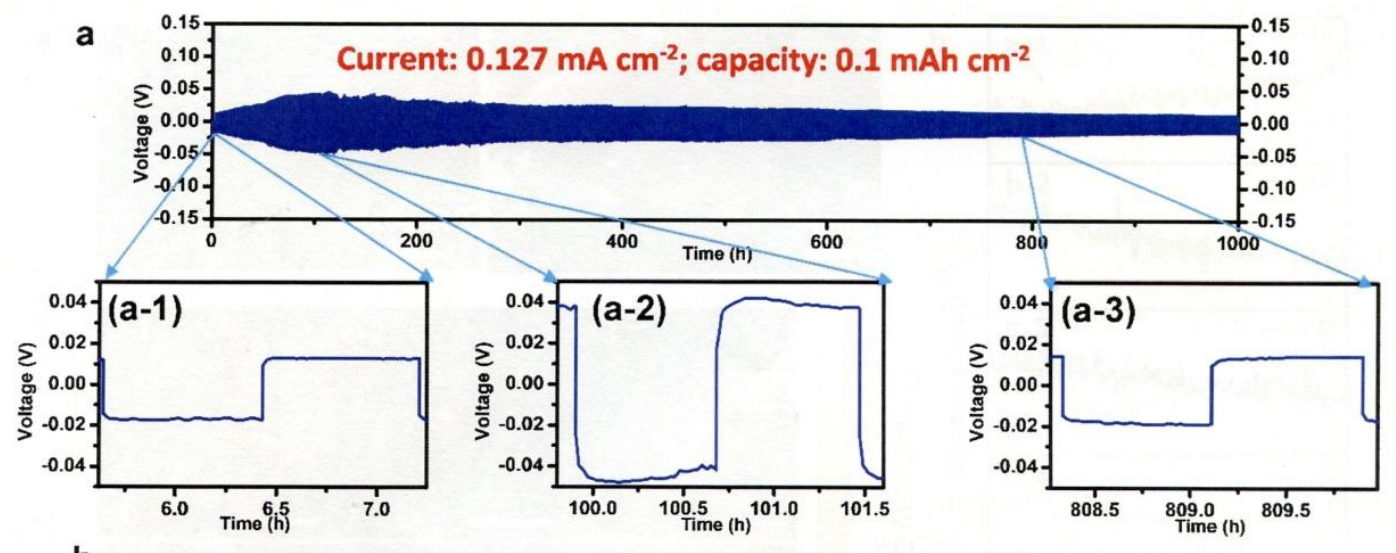

b

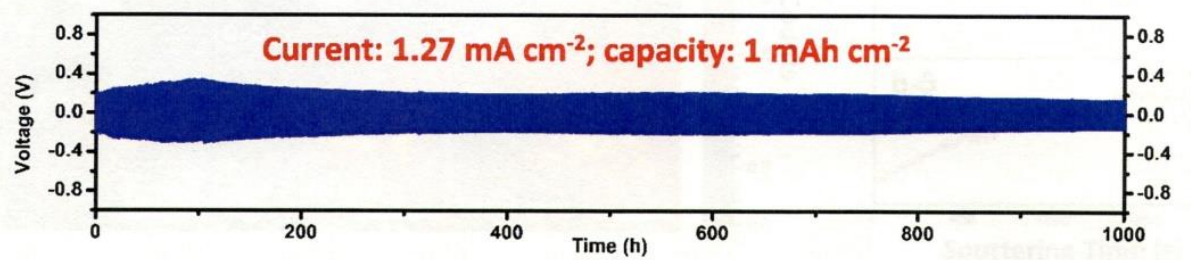

C

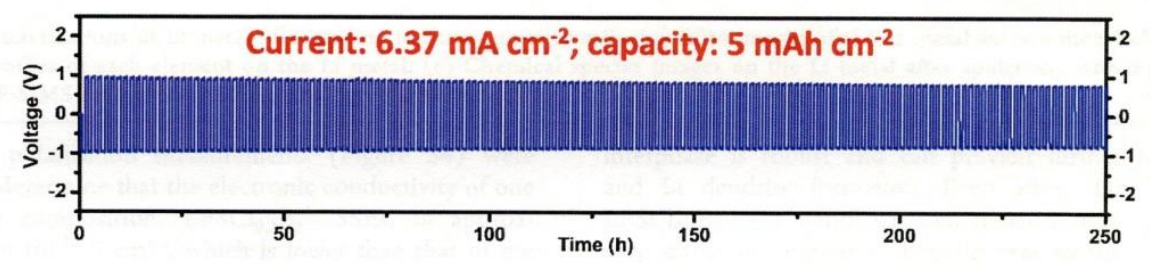

Figure $11 \mathrm{Li}$ plating and stripping performance for $\mathrm{Li} / \mathrm{Li}_{6} \mathrm{PS}_{5} \mathrm{Cl}_{0.3} \mathrm{~F}_{0.7} / \mathrm{Li}$ cells. (a) Current density $\left(0.127 \mathrm{~mA} \mathrm{~cm}^{-2}\right)$ and cut-off capacity $\left(0.1 \mathrm{mAh} \mathrm{cm}^{-2}\right)$. (a1-a3) Enlarged view of panel a. (b) Current density $\left(1.27 \mathrm{~mA} \mathrm{~cm}^{-2}\right)$ and cut-off capacity $\left(1 \mathrm{mAh} \mathrm{cm}^{-1}\right)$. (c) Current density $\left(6.37 \mathrm{~mA} \mathrm{~cm}^{-2}\right)$ and cut-off capacity $\left(5 \mathrm{~mA} \mathrm{~cm}^{-2}\right)$ [81].

Table 7 shows that cells with a lithium electrode and an inorganic solid electrolyte have been rarely studied under conditions of high current density and specific area capacity required for EV batteries. Excellent lithium plating and stripping cyclic performance at high current density was observed for $\mathrm{Li} / \mathrm{Li}_{6} \mathrm{PS}_{5} \mathrm{Cl}_{0.3} \mathrm{~F}_{0.7} / \mathrm{Li}$ and $1.27 \mathrm{In}-\mathrm{Li} / \mathrm{Li}_{3} \mathrm{PS}_{4} / 1.27 \mathrm{In}-\mathrm{Li}$ cells. However, the excellent performance of the former cell was obtained when the lithium plating and stripping pre-treatment process was conducted at a low current density to form a dense SEl. The 1.27In-Li alloy electrode exhibited excellent cycle performance, whereas the $1.23 \mathrm{In}-\mathrm{Li}$ alloy electrode exhibited poor performance.

Table 7 Polarization behavior of Li/solid electrolyte/Li cells at $25^{\circ} \mathrm{C}$.

\begin{tabular}{lllllll}
\hline Electrolyte and electrode & Conductivity & Cell & \multicolumn{3}{c}{ Polarization } & Ref. \\
& $\left(\mathrm{S} \mathrm{cm}^{-1}\right)$ & $\begin{array}{l}\text { resistanc } \\
\text { e } \Omega \mathrm{cm}^{2}\end{array}$ & $\begin{array}{l}\text { Current } \\
\left(\mathrm{mA} \mathrm{cm} \mathrm{cm}^{-2}\right)\end{array}$ & Period & (h) & Cycle \\
& & & & & & (number) \\
\hline
\end{tabular}




\begin{tabular}{|c|c|c|c|c|c|c|}
\hline \multirow[t]{2}{*}{$\mathrm{Li} / \mathrm{Li}_{6} \mathrm{PS}_{5} \mathrm{Cl}_{0.3} \mathrm{~F}_{0.7} / \mathrm{Li}$} & \multirow[t]{2}{*}{$5.2 \times 10^{-4}$} & \multirow[t]{2}{*}{130} & 6.37 & 0.78 & $>160$ & \multirow[t]{2}{*}{ [81] } \\
\hline & & & 1.27 & 0.79 & $>635$ & \\
\hline $\mathrm{Li} / \mathrm{Li}_{6.4} \mathrm{Al}_{0.2} \mathrm{La}_{3} \mathrm{Zr}_{2} \mathrm{O}_{12-2}-20$ & $2.5 \times 10^{-4}$ & 700 & 0.5 & 0.5 & $>1000$ & {$[90]$} \\
\hline \multicolumn{7}{|l|}{ wt\% PEO $_{18} \mathrm{LiTFSI} / \mathrm{Li}$} \\
\hline $\mathrm{Li} / \mathrm{Li}_{6.5} \mathrm{La}_{3} \mathrm{Zr}_{1.5} \mathrm{Nb}_{02.5} \mathrm{O}_{12} / \mathrm{Li}$ & $5.7 \times 10^{-4}$ & 750 & 0.5 & 0.08 & short & [102] \\
\hline $\mathrm{Li} / \mathrm{Li}_{6.75} \mathrm{La}_{3} \mathrm{Zr}_{1.75} \mathrm{Ta}_{0.25} \mathrm{O}_{12} / \mathrm{Li}$ & $7 \times 10^{-4}$ & 700 & 0 & 0.1 & short & [110] \\
\hline $\mathrm{Li} / 75 \mathrm{Li}_{2} \mathrm{~S}-25 \mathrm{P}_{2} \mathrm{~S}_{5} / \mathrm{Li}$ & $1.53 \times 10^{-4}$ & & 0.5 & 5 & short & [111] \\
\hline $\mathrm{Li} / \mathrm{Li}_{3} \mathrm{PS}_{4} / \mathrm{Li}$ & $2.6 \times 10^{-4}$ & 280 & 0.3 & 2 & 23 & [112] \\
\hline \multirow[t]{2}{*}{$\mathrm{Li} / \mathrm{Li}_{6.5} \mathrm{La}_{3} \mathrm{Zr}_{1.5} \mathrm{Ta}_{0.5} \mathrm{O}_{12} / \mathrm{Li}$} & & 363 & 0.2 & 0.5 & $>5$ & [113] \\
\hline & & & 0.3 & 0.5 & 5 & \\
\hline $\mathrm{Li}-\mathrm{G} / \mathrm{Li}_{10} \mathrm{GeP}_{2} \mathrm{~S}_{12} / \mathrm{Li}-\mathrm{G}$ & $1.2 \times 10^{-2}$ & & 0.25 & 1 & $>250$ & [106] \\
\hline $\mathrm{Li} / \mathrm{Li}_{10} \mathrm{GeP}_{2} \mathrm{~S}_{12} / \mathrm{Li}$ & $1.2 \times 10^{-2}$ & & 0.25 & 1 & 5 & [106] \\
\hline $\mathrm{Li}-/ 0.7 \mathrm{Li}\left(\mathrm{CB}_{9} \mathrm{H}_{10}\right)$ & $6.7 \times 10^{-3}$ & 28 & 0.2 & 1 & $>150$ & [108] \\
\hline \multicolumn{7}{|l|}{$0.3\left(\mathrm{CB}_{11} \mathrm{H}_{12}\right) / \mathrm{Li}$} \\
\hline $\mathrm{Li} / \mathrm{Li}_{6.25} \mathrm{Al}_{0.25} \mathrm{La}_{3} \mathrm{Zr}_{2} \mathrm{O}_{12} / \mathrm{Li}$ & & 250 & 0.2 & 2 & $>100$ & [107] \\
\hline $\begin{array}{l}\mathrm{Li} / \mathrm{Li}_{6,75} \mathrm{La}_{3} \mathrm{Zr}_{1,75} \mathrm{Ta}_{0.25} \mathrm{O}_{12-} \\
14 \text { wt\% BNP-TFSI/Li }\end{array}$ & $6.7 \times 10^{-4}$ & & 0.1 & 0.5 & $>300$ & [114] \\
\hline $\begin{array}{l}\mathrm{Li} / \mathrm{Li}_{6.25} \mathrm{Al}_{0.25} \mathrm{La}_{3} \mathrm{Zr}_{2} \mathrm{O}_{12-20} \\
\text { wt\% EMIMLiTFSI/Li }\end{array}$ & $1 \times 10^{-4}$ & 320 & 0.1 & 12 & $>38$ & [115] \\
\hline $\mathrm{Li} / \mathrm{Li}_{6.1} \mathrm{Ga}_{0.3} \mathrm{La}_{3} \mathrm{Zr}_{2} \mathrm{O}_{12} / \mathrm{Li}$ & $1 \times 10^{-3}$ & & 0.1 & 2 & $>50$ & [116] \\
\hline 1.27In-Li/Li $3 \mathrm{PS}_{4} / 1,27 \mathrm{In}-\mathrm{L}$ & $6.7 \times 10^{-4}$ & 350 & 1 & 1 & $>100$ & [109] \\
\hline
\end{tabular}

A deep plating and stripping cycle should be examined for developing the Li-In alloy anode. The increase in cell potential during the lithium deposition and stripping cycles in the Li/solid electrolyte/Li cell can be potentially attributed to the reaction between lithium and the solid electrolyte. In addition, several studies have reported the electrochemical instability of the sulfidebased lithium-ion conducting solid electrolytes under conditions of low voltage $[117,118]$. However, there has been no report on the CE of the lithium deposition and stripping processes in a solid electrolyte. The CE is an indicator of the reaction between the solid electrolyte and the lithium electrode. All-solid-state lithium batteries with lithium anodes are expected to be used for EVs because they address the present safety concerns and enable a wide operating temperature. They are considered to be promising next-generation batteries beyond lithium-ion batteries. However, the technology employed for developing all-solid-state lithium batteries is complex, particularly the methods followed to prepare the solid electrolyte thin film. High conductivity thin films of the sulfide-based solid electrolytes and the polymer and oxide lithium-ion conducting composite electrolytes are more easily prepared following casting methods.

\section{Conclusion}

A lithium metal anode coupled with a high-capacity cathode can be potentially used to develop a high energy density rechargeable battery $\left(>500 \mathrm{Wh} \mathrm{kg}^{-1}\right.$; specific energy density target for EV batteries). The formation of lithium dendrites at high current density $\left(>1 \mathrm{~mA} \mathrm{~cm}{ }^{-2}\right)$ should be 
avoided to develop efficient lithium anodes. A high specific area capacity $\left(>5 \mathrm{mAh} \mathrm{cm}^{-2}\right)$ and a high CE (>99.9\%) should be achieved to develop lithium anodes for rechargeable batteries. At present, non-aqueous liquid electrolytes without lithium dendrite formation and a high CE of more than 99.9\% have not been reported at a high current density of more than $1 \mathrm{~mA} \mathrm{~cm}^{-2}$. This hinders the practical application of the lithium anode. The lithiated NAFION thin layer on the lithium anode can improve the CE in lithium dendrite formation-free non-aqueous electrolytes. Solid electrolytes can be used to address the safety concerns; however, lithium dendrite-free solid electrolytes at high current density have not been reported to date (exception: lithium electrode pre-treated with a $\mathrm{Li}_{6} \mathrm{PS}_{5} \mathrm{Cl}_{0.3} \mathrm{~F}_{0.7}$ electrolyte). This solid electrolyte exhibited low interface resistance with a lithium electrode and no dendrite short-circuit was observed over 350 cycles at $6.37 \mathrm{~mA} \mathrm{~cm}{ }^{-2}$ and $5 \mathrm{mAh}$ $\mathrm{cm}^{-2}$. This electrolyte satisfies the dendrite formation-free requirement at high current density and specific area capacity. The lithium electrode was pre-treated at a low current density for a long cycle. A flexible composite electrolyte comprising a sheet of nanofibers of the garnet-type lithium-ion conducting solid electrolyte and a PEO-based polymer electrolyte showed excellent lithium deposition and stripping cycle performance at $0.5 \mathrm{~mA} \mathrm{~cm} \mathrm{~cm}^{-2}$ (at room temperature). The $\mathrm{Li} /$ composite electrolyte/Li cell resistance was as high as $700 \Omega \mathrm{cm}^{-2}$ at room temperature. A composite electrolyte that consists of inorganic and polymer components is thus attractive for the development of an electrolyte to fabricate an all-solid-state lithium battery because of its flexibility and high conductivity at room temperature.

\section{Author Contributions}

Nobuyuki Imanishi summarized all parts of this review. Daishuke Mori contributed to the parts on the solid electrolytes. Sou Taminato contributed to the parts on the polymer electrolytes. Yasuo Takeda contributed to summarize all parts of this review. Osamu Yamamoto contributed to the parts on the liquid electrolytes.

\section{Competing interests}

The authors have declared that no competing interests exist

\section{References}

1. Bresser D, Hosoi K, Howell D, Li H, Zeisel H, Amine K, et al. Perspectives of automotive battery R\&D in China, Germany, Japan, and the USA. J Power Sources. 2018; 382: 176-178.

2. Ding $Y$, Cano ZP, Yu A, Lu J, Chen Z. Automotive Li-ion batteries: Current status and future perspectives. Electrochem Energy Rev. 2019; 2: 1-28.

3. Van Noorden R. The rechargeable revolution: A better battery. Nature. 2014; 507: 26-28.

4. Bruce PG, Freunberger SA, Hardwick LJ, Tarascon JM. Li- $\mathrm{O}_{2}$ and Li-S batteries with high energy storage. Nat Mater. 2012; 11: 19-29.

5. Yamamoto O. The lithium air battery: Fundamentals. New York: Springer; 2013. pp.1-21.

6. Liu J, Bao Z, Cui Y, Dufek EJ, Goodenough JB, Khalifah P, et al. Pathways for practical high-energy long-cycling lithium metal batteries. Nat Energy. 2019; 4: 180-186.

7. Imanishi N, Yamamoto $\mathrm{O}$. Perspective and challenges of rechargeable lithium-air batteries. Mater Today Adv. 2019; 4: 100031. 
8. Liu J, Li L, Park JB, Sun YK, Wu F, Amine K. Aprotic and aqueous $\mathrm{Li}^{-\mathrm{O}_{2}}$ batteries. Chem Rev. 2014; 114: 5611-5640.

9. Zhang $P$, Zhao $Y$, Zhang $X$. Functional and stability orientation synthesis of materials and structures in aprotic $\mathrm{Li}_{-} \mathrm{O}_{2}$ batteries. Chem Soc Rev. 2018; 47: 2921-3004.

10. Abraham KM, Jiang Z. A polymer electrolyte-based rechargeable lithium/oxygen battery. J Electrochem Soc. 1996; 143: 1-5.

11. Fu J, Chen Z. Fundamentals and application in metal-air and metal sulphur batteries. New York: CRC press; 2017. pp.1-20.

12. Whittingham MS. Chemistry of intercalation compounds: Metal guests in chalcogenide hosts. Prog Solid State Chem. 1978; 12: 41-99.

13. Yoshino A. The birth of the lithium-ion battery. Angew Chem Int Ed. 2012; 51: 5798-5800.

14. Brissot C, Rosse M, Chazalviel JN, Lascaud S. Dendritic growth mechanism in lithium/polymer cells. J Power Sources. 1999; 81-82: 925-929.

15. Peled E. The Electrochemical behaviour of alkali and alkaline earth metals in nonaqueous battery systems-the solid electrolyte interphase model. J Electrochem Soc. 1979; 126: 20472051.

16. Liu S, Wang H, Imanishi N, Zhang T, Hirano A, Takeda Y, et al. Effect of co-doping nano-silica filler and $\mathrm{N}$-methyl-N-propylpiperidinium bis(trifluoromethanesulfonyl)imide into polymer electrolyte on Li dendrite formation in $\mathrm{Li} /$ poly(ethylene oxide)- $\mathrm{Li}\left(\mathrm{CF}_{3} \mathrm{SO}_{2}\right)_{2} \mathrm{~N} / \mathrm{Li}$. J Power Sources. 2011; 196: 7681-7686.

17. Wang H, Liu Y, Li Y, Cui Y. Lithium metal anode materials design: Interphase and host. Electrochem Energy Rev. 2019; 2: 509-517.

18. Cheng XB, Zhang $R$, Zhao CZ, Zhang $Q$. Toward safe lithium metal anode in rechargeable batteries: A review. Chem Rev. 2017; 117: 10403-10473.

19. Zhang K, Lee GH, Park M, Li W, Kang YM. Recent developments of the lithium metal anode for rechargeable non-aqueous batteries. Adv Energy Mater. 2016; 6: 1600811.

20. Xu W, Wang J, Ding F, Chen X, Nasybutin E, Zhang Y, et al. Lithium metal anodes for rechargeable batteries. Energy Environ Sci. 2014; 7: 513-537.

21. Aurbach D. Review of selected electrode-solution interactions which determine the performance of Li and Li ion batteries. J Power Sources. 2000; 89: 206-218.

22. Seong IW, Hong CH, Kim BK, Yoon WY. The effects of current density and amount of discharge on dendrite formation in the lithium powder anode electrode. J Power Sources. 2008; 178: 769773.

23. Zhang $\mathrm{O}$, Jin $\mathrm{H}$, Wang $\mathrm{T}$, Wang $\mathrm{M}$. Insight into the effect of lithium-dendrite suppression by lithium bis(fluorosulfony)imide/1, 2-dimethoxyethylene electrolytes. Electrochim Acta. 2018; 277: 116-126.

24. Park MS, Ma SB, Lee DJ, Im D, Doo SG, Yamamoto O. A high reversible lithium metal anode. Sci Rep. 2014; 4: 3815.

25. Lu W, Lopez CM, Liu N, Vaughey JT, Jansen A, Dennis D. Overcharge effect on morphology and structure of carbon electrodes for lithium-ion batteries. J Electrochem Soc. 2012; 159: A566A570.

26. Choudhury S, Archer LA. Lithium fluoride additives for stable cycling of lithium batteries at high current densities. Adv Electron Mater. 2016; 2: 1500246.

27. Li W, Yao H, Yan K, Zheng G, Liang Z, Chiang YM, et al. The synergetic effect of lithium polysulfide 
and lithium nitrate to prevent lithium dendrite growth. Nat Commun. 2015; 6: 7436.

28. Liu Y, Lin D, Li Y, Chen G, Pei A, Nix O, et al. Solubility-mediated sustained release enabling nitrate additive in carbonate electrolyte for stable lithium metal anode. Nat Commun. 2018; 9: 3656.

29. Liang X, Wen Z, Liu Y, Wu M, Jin J, Zhang H, et al. Improved cycling performances of lithium sulfur batteries with $\mathrm{LiNO}_{3}$-modified electrolyte. J Power Sources. 2011; 196: 9839-9843.

30. Cheng XB, Huang JQ, Zhang Q. Review-Li metal anode in working lithium-sulfur batteries. J Electrochem Soc. 2018; 165: A6058-A6072.

31. Xu X, Wang S, Wang H, Hu C, Jin Y, Liu J, et al. Recent progresses in the suppression method based on the growth mechanism of lithium dendrite. J Energy Chem. 2018; 27: 513-527.

32. Ding $F, X u$ W, Chen $X$, Zhang J, Engelhard MH, Zhang Y, et al. Effect of carbonate solvents and lithium salt on morphology and coulombic efficiency of lithium electrode. J Electrochem Soc. 2013; 160: A1894-A1901.

33. Miao R, Yang J, Xu Z, Wang J, Nuli Y, Sun L. A new ether-based electrolyte for dendrite-free lithium-metal based rechargeable batteries. Sci Rep. 2016; 6: 21771.

34. Naoi K, Mori M, Naruoka Y, Lamanna WM, Atanasoki R. The surface film formed on a lithium metal electrode in a new imide electrolyte, lithium bis(perfluoroethylsulfonylimide) $\mathrm{LiN}\left(\mathrm{C}_{2} \mathrm{~F}_{5} \mathrm{SO}_{2}\right)_{2}$. J Electrochem Soc. 1999; 146: 462-469.

35. Tu Z, Zachman MJ, Choudhury S, Wei S, Ma L, Yang Y, et al. Nanoporus hybrid electrolytes for high-energy batteries based on reactive metal anodes. Adv Energy Mater. 2017; 7: 1602367.

36. Suo L, Xue W, Gobet M, Greenbaum SG, Wang C, Chen Y, et al. Fluorine-donating electrolytes enable highly reversible 5-V-class Li metal batteries. PNAS. 2018; 115: 1156-1161.

37. Chen S, Zheng J, Mei D, Han KS, Engelhard MH, Zhao W, et al. High-voltage lithium-meal batteries enabled by localized high-concentration electrolytes. Adv Mater. 2018; 30: 1706102.

38. Fan X, Chen L, Ji X, Deng T, Hou S, Chen J, et al. Highly fluorinated interphases enable highvoltage Li-metal batteries. Chem. 2018; 4: 174-185.

39. Qian J, Henderson WA, Xu W, Bhattacharya P, Engelhard M, Borodin O, et al. High rate and stable cycling of lithium metal anode. Nat Commun. 2015; 6: 6362.

40. Pathak R, Chen K, Gurung A, Reza KM, Bahrami B, Pokaharel J, et al. Fluorinated hybrid solidelectrolyte-interphase for dendrite-free lithium deposition. Nat Commun. 2020; 11: 93.

41. Li Q, Zhu S, Lu Y. 3D porous Cu current collector/Li-metal composite anode for stable lithiummetal batteries. Adv Funct Mater. 2017; 27: 1606422.

42. Deng $W$, Zhu W, Zhou $X$, Peng $X$, Liu Z. Highly reversible Li plating confined in three-dimensional interconnected microchannel toward high-rate and stable metallic lithium anodes. ACS Appl Mater Interfaces. 2018; 10: 20387-20395.

43. Lee H, Lee DJ, Kim YJ, Park JK, Kim HT. A simple composite protective layer coating that enhances the cycling stability of lithium metal batteries. J Power Sources. 2015; 284:103-108.

44. Chang $\mathrm{CH}$, Chung SH, Manthiram A. Dendrite-free anode via a homogenous Li-ion distribution enabled by a Kimwipe paper. Adv Sustainable Syst. 2017; 1: 1600034.

45. Song J, Lee H, Choo MJ, Park JK, Kim HT. Ionomer-liquid electrolyte hybrid ionic conductor for high cycling stability of lithium metal electrodes. Sci Rep. 2015; 5: 14458.

46. Cha E, Patel MD, Park J, Hwang J, Prasad V, Cho K, et al. 2D MoS 2 as an efficient protective layer for lithium metal anode in high-performance Li-S batteries. Nat Nanotechnol. 2018; 13: 337343.

47. Shen X, Li Y, Qian T, Liu J, Zhou J, Yan C, et al. Lithium anode stable in air for low-cost fabrication 
of a dendrite-free lithium battery. Nat Commun. 2019; 10: 900.

48. Chi SS, Liu Y, Song L, Fan LZ, Zhang Q. Prestoring lithium into stable 3D nickel form host as dendrite-free lithium metal anode. Adv Funct Mater. 2017; 1700348.

49. Zhao J, Liao L, Shi F, Lei T, Chen G, Pei A, et al. Surface fluorination of reactive battery anode materials for enhanced stability. J Am Chem Soc. 2017; 139: 11550-11558.

50. Zheng XX, Yin YX, Shi Y, Zhang XD, Yao HR, Wen R. et al. Lithiation-derived repellent toward lithium anode safeguard in quasi-solid batteries. Chem. 2018; 4: 298-307.

51. Choudhury S, Tu Z, Stalin S, Vu D, Fawole K, Gunceler D, et al. Electroless formation of hydride lithium anodes for fast interfacial ion transport. Angew Chem Int Ed. 2017; 56: 13070-13077.

52. Liang Z, Lin D, Zhao J, Lu Z, Liu Y, Liu C, et al. Composite lithium metal anode by melt infusion of lithium into a 3D conducting scaffold with lithiophilic coating. PNAS. 2016; 113: 2862-2867.

53. Liu L, Yin YX, Li JY, Wang SH, Guo YG, Wan LJ. Uniform lithium nucleation/growth induced by lightweight nitrogen-doped graphitic carbon foams for high-performance lithium metal anode. Adv Mater. 2018; 30: 1206216.

54. Lin D, Liu Y, Liang Z, Lee HW, Sun J, Wang H, et al. Layered reduced graphene oxide with nanoscale interlayer gaps as stable host for lithium metal anode. Nat Nanotech. 2016; 11: 626632.

55. Liu L, Yin YX, Li JY, Guo YG, Wan LJ. Ladderlike carbon nanoarrays on 3D conducting skeletons enable uniform nucleation for stable lithium metal anodes. Chem Commun. 2018; 54: 53305333.

56. Zhao CZ, Cheng XB, Zhang R, Peng HJ, Hang JQ, Ran R, et al. $\mathrm{Li}_{2} \mathrm{~S}_{5}$-based ternary-salt electrolyte for robust lithium metal anode. Energy Storage Mater. 2016; 3: 77-84.

57. Eijima S, Sonoki H, Matsumoto M, Taminato S, Mori D, Imanishi N. Solid electrolyte interface film on lithium metal anode in mixed salt system. J Electrochem Soc. 2019; 166: A5421-A5429.

58. Cheng XB, Yan C, Chen X, Guan C, Huang JQ, Peng HJ, et al. Implantable solid electrolyte interphase in lithium-metal batteries. Chem. 2017; 2: 258-270.

59. Li NW, Yin YX, Yang CP, Guo YG. An artificial solid electrolyte interphase layer for stable lithium metal anodes. Adv Mater. 2016; 28: 1853-1858.

60. Yang F, Wang D, Zhao Y, Tsui KL, Bar SJ. A study of the relationship between coulombic efficiency and capacity degradation of commercial lithium-ion batteries. Energy. 2018; 145: 486-495.

61. Madani SS, Schaltz E, Kaer SK. Effect of current rate and prior cycling on the coulombic efficiency of a lithium-ion battery. Batteries. 2019; 5: 57.

62. Chen Y, Wen K, Chen T, Zhang X, Armand M. Recent progress in all-solid-state batteries: The emerging strategies for advanced electrolytes and their interfaces. Energy Storage Mater. 2020; 31: 401-433.

63. Mead RT. Solid state battery. Alexandria, VA: United States Patent and Trademark Office: 1973; US3773557A.

64. Shlaikler CR, Liang CG. Fast ion transport in solid. Amsterdam: North Holland; 1973. pp.685.

65. Gauthier M, Fauteux D, Vassort G, Belanger A, Duval M, Ricoux P, et al. Assessment of polymerelectrolyte batteries for EV and ambient temperature applications. J Electrochem Soc. 1985; 132: 1333-1339.

66. Gauthier M, Belanger A, Bouchard P, Kaper B, Richard S, Vassort G, et al. Large lithium polymer battery development the immobile solvent concept. J Power Sources. 1995; 54: 163-169.

67. Liu S, Imanishi N, Zhang T, Hirano A, Takeda Y, Yamamoto O, et al. Lithium dendrite formation in 
Li/poly(ethylene oxide)-lithium bis(trifluoromethanesulfonyl)imide and N-methyl-Npropylpiperidium bis(trifluoromethanesulfonyl)imide/Li cells. J Electrochem Soc. 2010; 157: A1092-A1098.

68. Kato Y, Hori S, Saito T, Suzuki K, Hirayama M, Mitsui A, et al. High power all-solid-state batteries using sulphide super ionic conductor. Nat Energy. 2016; 1: 16030.

69. Morita M, Ishikawa M, Matsuda Y. Organic electrolytes for rechargeable. In: Lithium ion batteries. Tokyo: Kodansha; 1998. pp.156-180.

70. Zhao Y, Daemen LL. Superionic conductivity in lithium-rich anti-perovskites. J Am Chem Soc. 2012; 134: 15042-15047.

71. Kim S, Oguchi H, Toyama N, Sato T, Takagi, Otomo T, et al. A complex hybrid lithium superionic conductor for high-energy-density all solid-state lithium metal batteries. Nat Commun. 2019; 10: 1018.

72. Asano T, Sakai A, Ouchi S, Sakaida M, Miyazaki A, Hasegawa S. Solid halide electrolyte with high lithium-ion conductivity for application in $4 \mathrm{~V}$ class bulk-type all-solid-state batteries. Adv Mater. 2018; 30: 1803075.

73. Li L, Wang M, Wang J, Ye F, Wang S, Xu Y, et al. Asymmetric gel polymer electrolyte with high lithium ion conductivity for dendrite-free lithium metal batteries. J Mater Chem A. 2020; 8: 8033-8040.

74. Sylla S, Sanchez, JY, Armand M. Electrochemical study of linear and crosslinked PEO-based polymer electrolyte. Electrochim Acta. 1992; 37: 1699-1701.

75. Wang J, Li S, Zhao Q, Song C, et al. Structure code for advanced polymer electrolyte in lithiumion batteries. Adv Funct Mater. 2020; 31: 2008208.

76. Xu H, Chien PH, Shi J, Li Y, Wu N, Liu Y, et al. High-performance all-solid-state batteries enabled by salt bonding to perovskite in poly(ethylene oxide). PNAS. 2019; 116: 18815-18821.

77. Wu N, Chen PH, Li Y, Dolocan A, Xu H, Xu B, et al. Fast $\mathrm{Li}^{+}$conduction mechanism and interfacial chemistry of a NASICON/polymer composite electrolyte. J Am Chem Soc. 2020; 142: 2497-2505.

78. Abraham KM, Alamgir M. Li+-conductive solid polymer electrolytes with liquid-like conductivity. J Electrochem Soc. 1990; 137: 1657-1658.

79. Lee HT, Ngo DT, Kalubarme RS, Cao G, Park GN, Park CJ. Composite gel polymer electrolyte based on poly(vinylidene fluoride-hexafluoropropylene) (PVDF-HFP) with modified aluminium-doped lithium lanthanum titanate (A-LLTO) for high-performance lithium rechargeable batteries. ACS Appl Interfaces. 2016; 8: 20710-20719.

80. Kamaya N, Homma K, Yamakawa Y, Hirayama M, Kanno R, Yomenura M, et al. A lithium superionic conductor. Nat Mater. 2011; 10: 682-686.

81. Zhao F, Sun Q, Yu C, Zhang S, Adair K, Wang S, et al. Ultrastable anode interface achieved by fluorinating electrolytes for all-solid-state Li metal batteries. ACS Energy Lett. 2020; 5: 10351043.

82. Aono H, Sugimoto E, Sadaoka Y, Imanaka N, Adachi G. Ionic conductivity of solid electrolytes based on lithium titanium phosphate. J Electrochem Soc. 1990; 137: 1023-1027.

83. Zhang $P$, Matsui $M$, Hirano $A$, Takeda $Y$, Yamamoto $O$, Imanishi $N$. Water-stable lithium ion conducting solid electrolyte of the $\mathrm{Li}_{1.4} \mathrm{Al}_{0.4} \mathrm{Ti}_{1.6-\mathrm{x}} \mathrm{Ge}_{\mathrm{x}}\left(\mathrm{PO}_{4}\right)_{3}$ system $(\mathrm{x}=0-1.0)$ with NASICON type structure. Solid State Ionics. 2013; 253: 175-180.

84. Murugan $\mathrm{R}$, Thangadurai $\mathrm{V}$, Weppner $\mathrm{W}$. Fast lithium ion conduction in garnet-type $\mathrm{Li}_{7} \mathrm{La}_{3} \mathrm{Zr}_{2} \mathrm{O}_{12}$. Angew Chem Int Ed. 2007; 46: 7778-7781. 
85. Qin S, Zhu X, Jiang Y, Ling M, Hu Z, Zhu J. Growth of self-textured Ga ${ }^{3+}$-substituted $\mathrm{Li}_{7} \mathrm{La}_{3} \mathrm{Zr}_{2} \mathrm{O}_{12}$ ceramics by solid state reaction and their significant enhancement in ionic conductivity. Appl Phys Lett. 2018; 112: 113901.

86. Inaguma $\mathrm{Y}$, Liquan $\mathrm{C}$, Ito $\mathrm{M}$, Nakamura $\mathrm{T}$, Uchida $\mathrm{T}$, Ikuta $\mathrm{H}$, et al. High ionic-conductivity in lithium lanthanum titanate. Solid State Commun. 1993; 86: 689-693.

87. Lapp T, Skaarup S, Hopper A. Ionic conductivity of pure and doped $\mathrm{Li}_{3} \mathrm{~N}$. Solid State Ionics. 1983; 11: 97-103.

88. Wan J, Xie J, Kong X, Liu Z, Liu K, Shi F, et al. Ultrathin, flexible, solid polymer composite electrolyte enabled with aligned nanoporous host for lithium batteries. Nat Nanotech. 2019; 14: 705-711.

89. Biensan Ph, Simon B, Peres JP, de Guibert A, Broussely M, Bodet J M, et al. On safety of lithiumion cells. J Power Sources. 1999; 81-82: 906-912.

90. Fu K, Gong Y, Dai J, Gong A, Han X, Yao Y, et al. Flexible solid-state, ion conducting membrane with 3D garnet nanofiber networks for lithium batteries. PNAS. 2016; 113: 7094-7099.

91. Zhao Y, Ding Y, Li Y, Peng L, Byon HR, Goodenough JB, et al. A chemistry and material perspective on lithium redox flow batteries toward high-density electrical energy storage. Chem Soc Rev. 2015; 44: 7968-7996.

92. Liu S, Imanishi N, Zhang T, Hirano A, Takeda $Y$, Yamamoto O, et al. Effect of nano-silica filler in polymer electrolyte on $\mathrm{Li}$ dendrite formation in $\mathrm{Li} /$ poly(ethylene oxide)- $\mathrm{Li}\left(\mathrm{CF}_{3} \mathrm{SO}_{2}\right)_{2} \mathrm{~N} / \mathrm{Li}$. J Power Sources. 2010; 195: 6847-6853.

93. Chen L, Li Y, Li SP, Fan LZ, Na CW, Goodenough JB. PEO/garnet composite electrolyte for solidstate lithium batteries: From ceramic-in polymer to polymer-in ceramic. Nano Energy. 2018; 46: 176-184.

94. Shim J, Kim HJ, Kim BG, Kim YS, Kim DG, Lee JC. 2D boron nitride nanoflakes as a multifunctional additive in gel polymer electrolytes for safe, long cycle life and high rate lithium metal batteries. Energy Environ Sci. 2017; 10: 1911-1916.

95. Zhang F, Kotobuki M, Song S, Lai MO, Lu Li. Review on solid electrolytes for all-solid-state lithiumion batteries. J Power Sources. 2018; 389: 198-213.

96. Imanishi N, Hasegawa S, Zhang T, Hirano A, Takeda Y, Yamamoto O. Lithium anode for lithiumair secondary batteries. J Power Sources. 2008; 185: 1392-1397.

97. Sunahiro S, Matsui M, Takeda Y, Yamamoto O, Imanishi N. Rechargeable aqueous lithium-air batteries with an auxiliary electrode for the oxygen evolution. J Power Sources. 2014; 262: 338343.

98. Inaguma $\mathrm{Y}$, Nakashima $\mathrm{M}$. A rechargeable lithium-air battery using a lithium ion conducting lanthanum titanate ceramics as an electrolyte separator. J Power Sources. 2013; 228: 250-255.

99. Zhang $P$, Imanishi N, Shimonishi $Y$, Hirano A, Takeda $Y$, Yamamoto $O$, et al. A novel high energy density rechargeable lithium/air battery. Chem Commun. 2010; 46: 1661-1663.

100.Monroe C, Newman J. The impact of elastic deformation on deposition kinetics at lithium/polymer interfaces. J Electrochem Soc. 2005; 152: A396-A404.

101.Ni JE, Case ED, Sakamoto JS, Rangasamy E, Wolfenstine JB. Room temperature elastic moduli and Vickers hardness of hot-pressed LLZO cubic garnet. J Mater Sci. 2012; 47: 7978-7985.

102.Ishiguro K, Nakata Y, Matsui M, Uechi Y, Takeda Y, Yamamoto O, et al, Stability of Nb-doped cubic $\mathrm{Li}_{7} \mathrm{La}_{3} \mathrm{Zr}_{2} \mathrm{O}_{12}$ with lithium metal. J Electrochem Soc. 2013; 160: A1690-A1693.

103.Sudo R, Ishiguro K, Matsui M, Hirano A, Takeda Y, Yamamoto O, et al. Interface behavior between 
garnet-type lithium-ion conducting solid electrolyte and lithium metal. Solid State Ionics. 2014; 262: 151-154.

104.Ishiguro K, Nemori H, Sunahiro S, Nakata Y, Sudo R, Matsui M, et al. Ta-doped $\mathrm{Li}_{7} \mathrm{La}_{3} \mathrm{Zr}_{2} \mathrm{O}_{12}$ for water-stable lithium electrode for lithium-air batteries. J Electrochem Soc. 2014; 161: A678A674.

105.Suzuki Y, Kami K, Watanabe K, Watanabe A, Saito N, Ohnishi T, et al. Transparent cubic garnettype solid electrolyte of Al2O3 doped $\mathrm{Li}_{7} \mathrm{La}_{3} \mathrm{Zr}_{2} \mathrm{O}_{12}$. Solid State lonics. 2015; 278: 172-176.

106.Su Y, Ye L, Fitzhugh W, Wang Y, Gil-Gonzalez E, Kim I, et al. A more stable lithium anode by mechanical constriction for solid state batteries. Energy Environ Sci. 2020; 13: 908-916.

107.Sharafi A, Karyak E, Davis A L, Yu S, Thompson T, Siegel DJ, et al. Surface chemistry mechanism of ultra-low interfacial resistance in the solid-state electrolyte $\mathrm{Li}_{7} \mathrm{La}_{3} \mathrm{Zr}_{2} \mathrm{O}_{12}$. Chem Mater. 2017; 29: 7961-7968.

108. Kim S, Oguchi H, Toyama N, Sato T, Takagi S, Otomo T, et al. A complex hydride lithium superionic conductor for high-energy-density all-solid-state lithium metal batteries. Nat Commun. 2019; 10: 1081.

109.Santhosha AL, Medenbach L, Buchheim JR, Adelhelm P. The indium-lithium electrode in solidstate lithium-ion batteries: Phase formation, redox potentials, and interface stability. Batteries Supercaps. 2019; 2: 524-529.

110. Ren Y, Shen Y, Lin Y, Nan CW. Direct observation of lithium dendrites inside garnet-type lithiumion solid electrolyte. Electrochem Commun. 2015; 57: 27-30.

111.Garcia-Mendez R, Mizuno F, Zhanga R, Arther TS, Sakamoto J. Effect of processing conditions of $75 \mathrm{Li}_{2} \mathrm{~S}-25 \mathrm{P}_{2} \mathrm{~S}_{5}$ solid electrolyte on its DC electrochemical behavior. Electrochim Acta. 2017; 237: 144-151.

112. Fan X, Ji X, Han F, Yue J, Chen J, Chen L, et al. Fluorinated solid electrolyte interphase enable highly reversible solid-state Li metal battery. Sci Adv. 2018; 4: 9245.

113. Basappa RH, Ito T, Yamada H. Contact between garnet-type solid electrolyte and lithium metal anode: Influence on charge transfer resistance and short circuit prevention. J Electrochem Soc. 2017; 164: A666-A671.

114.Zhang Z, Zhang L, Liu Y, Wang H, Yu C, Zeng H, et al. Interface-engineered $\mathrm{Li}_{7} \mathrm{La}_{3} \mathrm{Zr}_{2} \mathrm{O}_{12}$-based garnet solid electrolytes with suppressed $\mathrm{Li}$-dendrite formation and enhance electrochemical performance. ChemSusChem. 2018; 11: 3774-3782.

115. Wang $Z$, Wang $Z$, Yang $L$, Wang $H$, Song $Y$, Han $L$, et al. Boosting interfacial $\mathrm{Li}^{+}$transport with a MOF-based ionic conductor for solid-state batteries. Nano Energy. 2018; 49: 580-587.

116.Wu B, Wang S, Lochala J, Desrochers D, Liu B, Zhang W, et al. The role of the solid electrolyte interphase layer in preventing Li dendrite growth in solid-state batteries. Energy Environ Sci. 2018; 11: 1803-1810.

117.Zhu Y, He H, Mo Y. First principles study on electrochemical and chemical stability of solid electrolyte-electrode interface in all-solid-state Li-ion batteries. J Mater Chem A. 2016; 4: 32533366.

118.Ong SP, Mo Y, Richards WD, Miara L, Lee HS, Ceder G. Phase stability, electrochemical stability and ionic conductivity of the $\mathrm{Li}_{10 \mp 1} \mathrm{MP}_{2} \mathrm{X}_{12}(\mathrm{M}=\mathrm{Ge}, \mathrm{Si}, \mathrm{Sn}, \mathrm{Al}$ or $\mathrm{P}, \mathrm{X}=\mathrm{O}, \mathrm{S}$ or Se) family superionic conductors. Energy Environ Sci. 2013; 6: 148-156. 


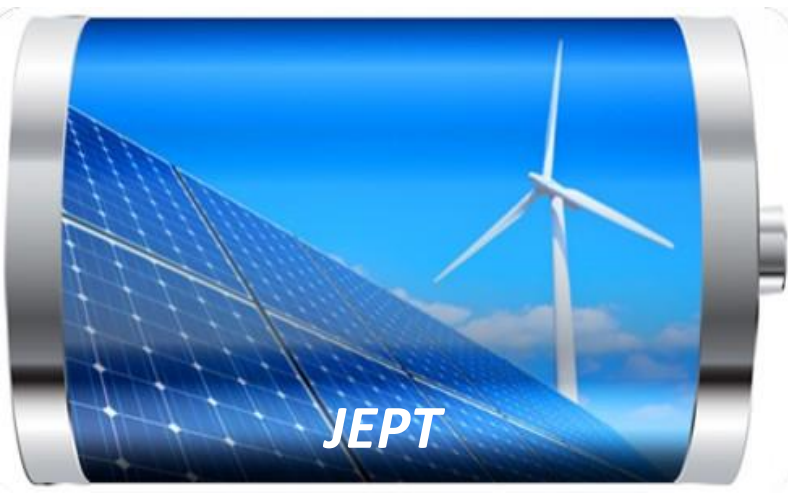

Enjoy JEPT by:

1. Submitting a manuscript

2. Joining in volunteer reviewer bank

3. Joining Editorial Board

4. Guest editing a special issue

For more details, please visit: http://www.lidsen.com/journal/jept 